
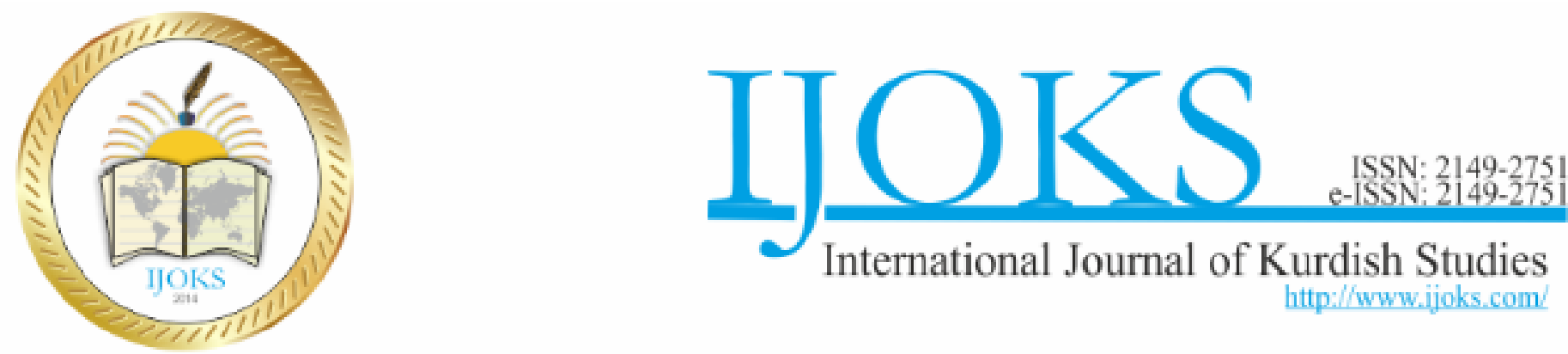

Article

International Journal of Kurdish Studies

5 (2), pp. $393-421$

http://www.ijoks.com

\title{
Enformel Arabulucuların Mikro Çatışma Çözümündeki Rolleri: Diyarbakır Örneği ${ }^{1}$
}

\author{
Ferda FAHRIOĞLU AKIN
}

Received: Mar 21, 2019

Reviewed: Mar 23, 2019

Accepted: Mar 24, 2019

\section{$\ddot{O} \mathbf{z}$}

Mikro çatışma olarak tanımlanan öldürme, kan davası, kız kaçırma ve arazi meseleleri gibi toplumsal sorunların çözümü için başvurulan resmi hukuki yöntemlerin yetersiz kaldığı görülmektedir. Geleneksel toplumlarda resmi hukuk sisteminin tek başına çatışmayı çözemediği bu tür suç durumlarında, geleneksel bir hukuk yöntemi olan arabuluculuk devreye girmektedir. Çalışmanın konusu, geleneksel bir hukuk yöntemi olan enformel arabuluculuk yöntemi ile mikro çatışmaların nasıl çözüldüğ̈ün̈n incelenmesidir. Çatışma Çözümü Literatüründe geleneksel hukuk ve/veya enformel hukuk olarak da tanımlanan arabuluculuk yönteminin resmi hukuk sistemine "paralel" ya da "alternatif" olmadığı ve "tamamlayıcı" bir rol üstlendiği görülmektedir. Çalışmanın saha verileri Diyarbakır'da yapılan beş aylık saha çalışmasına dayanmaktadır. Bu çalışmada nitel araştırma yöntemlerinden derinlemesine görüşme, sözlü tarih, katılımlı gözlem ve odak grup görüşmeleri yöntemlerine başvurulmuştur. Kartopu yöntemi ile seçilen 50 görüşmeci ile derinlemesine görüşme gerçekleştirilmiştir. Çalışmada, kanaat önderleri tarafından yürütülen enformel arabuluculuk sistemi çatışma çözümünde ve arabuluculuk literatürü perspektifinde incelenmiş olup saha verileri dünyadaki benzer ve farklı vakalarla karşılaştırmalı olarak incelenmiştir.

Anahtar Kelimeler: Çatışma Çözümü, Enformel Hukuk, Enformel Arabuluculuk, Diyarbakır, Mikro Çatışmalar.

\section{Recommended citation:}

Fahrioğlu Akın, F. (2019). Enformel Arabulucuların Mikro Çatışma Çözümündeki Rolleri: Diyarbakır Örneği. International Journal of Kurdish Studies 5 (2), 393 - 421 DOI: 10.21600/ijoks.543133

\footnotetext{
${ }^{1}$ Bu çalışma Prof. Dr. Elçin MACAR danışmanlığında yazılan doktora tez çalışmasından üretilmiştir.

${ }^{2}$ Yıldız Teknik Üniversitesi, ilBF, Siyaset Bilimi ve Uluslararası illişkiler Bölümü, Doktora Öğrencisi, ffahrioglu@gmail.com. ORCID No : 0000-0002-0397-1828
} 
The Role of "Informal Mediators" in Micro-Conflict Resolution: Diyarbakır

\title{
Case
}

\begin{abstract}
Official law often fails to solve the "micro-conflicts" of society, those being the likes of murder, abduction, and land disputes. In these kinds of situations, in which the official law system alone does not or can not solve conflicts, the mediation method of traditional society becomes useful. The aim of this work is to examine how micro-conflicts are resolved via informal mediation methods, or "traditional law" methods. Informal mediation, known as the traditional or informal law method in conflict resolution literature, is not an alternative to formal law; it serves to complement formal law. The data used in this paper was collected through five months of field work done in Diyarbakır. This data is analyzed alongside qualitative research such as in-depth interviews, oral histories, and focus group findings. This study is examined informal mediation method, which is done by opinion leaders, from Conflict Resolution and Mediation literatüre perspectives. Field work data from Diyarbakir is compared with data from different cases in other countries.
\end{abstract}

Key Words: Conflict Resolution, Informal Law, Informal Mediation, Diyarbakır, Micro Conflicts.

\section{GíRIŞ}

Uluslararası ilişkiler disiplini altında bulunan çatışma çözümü literatüründe bireyler arasında, grup içinde ve gruplar arasında meydana gelen ve mikro çatışmalar olarak belirtilen toplumsal çatışmaların çözümünde resmi mahkemeler dışında devlet dışı aktörlerin de rol aldıkları belirtilmektedir. Bu çalışma Türkiye'de Kürtlerin yoğunluklu olarak yaşadıkları coğrafyada mikro çatışmaların çözümünde devlet dışı aktör olarak enformel arabulucuları rol aldıkları için onlarında incelenmesi fikrinden doğmuştur. Araştırmada, Türkiye kamuoyunda devlet dışı aktörlerin çatışma çözümündeki rolleri ve "alternatif mahkemeler" veya "paralel mahkemeler" ya da "PKK mahkemeleri" şeklinde telaffuz edilen, bir enformel hukuk sisteminin olup olmadığı, bunun resmi hukuka tehdit oluşturup oluşturmadığının araştırılması amaçlanmıştır.

Araştırma, devlet dış1 aktör olarak mikro çatışma çözümünde etkili olan aktörlerin nası1 alternatif ve paralel bir sistem kurmuş olabilecekleri sorusu ile Diyarbakır'da saha çalışmasına başlamıştır. Yapılan saha çalışması sonrasında günümüzde etkili olan enformel hukuk sisteminin toplumdaki geleneksel hukuk sisteminin siyasi parti çatısı altında yeniden inşa edildiği ve bir dönüşüm geçirdiği görülmüştür. Mikro çatışma çözümündeki temel aktörlerin enformel arabulucular olan kanaat önderleri olduğu görülmüştür. Saha çalışmasından sonra tekrar çatışma çözümü literatüründeki arabuluculuğa dair tartışmalar incelenip çalışmanın odaklandığı sahadan elde edilen verilerin literatürde nereye oturduğu araştırılmıştır. Bu çalışmada çatışma çözümünde arabuluculuk literatüründe bulunan ikincil ve üçüncül kaynaklarındaki tartışmalar incelenmiş olup saha çalışması için de Diyarbakır ili seçilmiştir. Beş ay süren saha çalışmasında araştırma açık uçlu soruların sorulduğu 50 kişi ile derinlemesine görüşmeler gerçekleştirmiştir. Kartopu yöntemi ile seçilmiş 10'u kadın 40'1 erkek 50 kişi ile derinlemesine görüşme gerçekleştirilmiştir. Kadın görüşmecilerin yaş 
ortalaması 43, erkek görüşmecilerin yaş ortalamaları 61 iken genel yaş ortalaması 52 'dir. Bu görüşmecilerden 27'isi Rusipî olarak tanımlanan kanaat önderlerinden oluşmaktadır. Altı ayrı ilçeden bulunan altı farklı köyde bulunan Rusipîler ve il merkezinde görüşülen Rusipîlerden 17'si Hacı, Mele, Seyda, Şeyh gibi dini unvanlarla tanınmaktaydı. Ayrıca HDP, DBP, Hüdapar, AKP, CHP, MHP ve Saadet Partisi olmak üzere yedi siyasi partinin ağırlıklı olarak Halklar İlişkiler Birimlerinde görevli kişiler olmak üzere çeşitli birimlerinde görevli 20 kişi ile görüşmeler yapıldı. Bu kişiler arasında da 17 kişi dini bir unvana sahipti. Siyasi partilerden görüşülen bazı kişiler de ayrıca rusipî tanımlamasına girdiği için bu kişiler her iki gruba da dâhil edilmiştir. Ayrıca araştırmacı diğer nitel araştırma teknikleri (Kümbetoğlu, 2012) olan odak grup görüşmeleri, sözlü tarih yöntemi ve katılımcı gözlemci yöntemlerine de başvurmuştur. Görüşmecilerin belirlenmesinde kartopu yöntemi (Yıldırım ve Şimşek, 2013) kullanılmış olup saha çalışmasına son verilmesinde de araştırmanın doyum noktasına ulaştığını gösteren teorik örneklem yönteminden faydalanılmıştır.

Bu çalışmanın temel savı, geleneksel özelliklerini koruyan toplumlarda Batı'dan alınan hukuk kuralları ile inşa edilen resmi hukukun, toplumsal çatışmaların çözümünde yetersiz kaldığı ve çatışmanın tarafları arasında toplumsal barışın sağlanabilmesi için toplum tarafından kabul gören enformel arabulucuların uyguladıkları enformel hukuk kuralları ile mikro çatışmaların çözümünde daha etkili oldukları için enformel arabuluculuk yönteminin resmi hukukun “tamamlayıcısı” olduğudur. Bu sav, gerek çatışma çözümünde arabuluculuk literatüründeki tartışmalar ile gerekse de Haziran-Ekim 2017 tarihleri arasında yapılan saha çalışmasından elde edilen veriler ile desteklenmektedir. Teorik çerçevenin ilk bölümünde çatışma çözümünde arabuluculuk literatüründe resmi ve enformel arabuluculuk yöntemlerinin tarihçesi, gelişimi ve dönüşümü teorisyenlerin çalışmaları çerçevesinde tartışılmış ve bu alanda günümüzde hem batı hem de doğu kültürlerinde var olan örnekler üzerinden incelenmiştir. Teorik çerçevenin ikinci bölümünde saha çalışmasının yapıldığ 1 coğrafyada da İslami kültürün etkileri görüldügü için İslami kültürde enformel arabuluculuk yöntemi ile barıştırma gelenekleri incelenmiştir. $\mathrm{Bu}$ inceleme yapılırken hem çatışma çözümü literatüründe yer alan dini-barış inşası tartışmaları incelenmiş hem de İslami kültürünün etkili olduğu bazı ülkelerde günümüzde de facto olarak uygulanan enformel arabuluculuk yöntemleri araştırılmıştır. Teorik çerçevenin son bölümünde ise çalışmanın yapıldığ Türkiye'deki arabuluculuk uygulamaları incelenmiştir. Resmi arabuluculuk yöntemi ile farklılıklarının anlaşılabilmesi için öncelikle 2000'lerin başından itibaren uygulanmaya başlanan resmi arabuluculuk uygulamaları araştırılıp sonrasında kanaat önderleri tarafindan gerçekleştirilen enformel arabuluculuk yöntemi tartışılmıştır. Türkiye'de enformel arabuluculuk yönteminin anlaşılabilmesi için barıştırmanın etkili olduğu sosyolojik yapının incelenmesi gerekli görülmüştür. Dünyadaki, İslami kültürdeki ve Türkiye coğrafyasındaki arabuluculuk yöntemi ile barıştırma uygulamaları ve geleneklerinin incelendiği teorik çerçeve saha çalışmasının yapıldığı Diyarbakır örneğinin anlaşılabilmesi için elzem nitelikte görülmüştür. Makalede çalışma ayrıntıları ile aktarılamayacağı için elde edilen bulgular sonuç kısmında ayrıntılı olarak aktarılacaktır.

\section{Çatışma Çözümünde Arabuluculuk Yöntemi}


Davis ve Dugan $(1982,85)$, arabuluculuk kavramını nötr olan üçüncü bir tarafın teknik olarak görüşme sürecini yürüttüğü ve nihayetinde bir anlaşmaya varılmasını sağladığı yöntem olarak tanımlamaktadırlar. Bercovitch $(1992,6)$ ise arabuluculuğu, çatışan tarafların tek başlarına çözemedikleri bir çatışma için bir birey, grup, devlet ya da kuruluştan yardım istemeleri veya gelen yardım teklifini kabul etmeleri ile çatışmaya dair fikirlerinin baskı olmadan değiştiği çatışma yönetimi süreci olarak tanımlamaktadır. Resmi ve enformel arabuluculuk olarak ikiye ayrılan yöntemde resmi arabuluculuğun geleneksel arabuluculuğun yeniden inşa edilmesi ile ortaya çıktığı görülmektedir. Milattan önce 2000 yıllarına kadar dayandırılan (Bercovitch, 1992) ve günümüzde de etkili olan arabuluculuk yönteminin devletlerin ve mahkemelerin kendilerine tehdit olarak görmesi sonucu 1960'l1 yıllarda arabuluculuk yönteminin resmileştirmeye çalışıldığı görülmektedir (Saxon, 2018). Arabuluculuk yönteminin resmileşme süreci çeşitli akademi ve enstitülerin girişimleri ile kurulan bağımsız arabuluculuk programları ile gerçekleşmiştir (Bush ve Folger, 2005). Kuzey Amerika'da ortaya çıkan ve sayıları hızla artıp dünyanın pek çok ülkesine yayılan arabuluculuk programlarının başarısı modern çağda hukukun revize edilmesine ihtiyaç duyulduğunu gösterdiği için Avrupa Konseyi, Avrupa Birliği ve Birleşmiş Milletler resmi arabuluculuk uygulamasını programlarına dâhil etmişlerdir (Tunç, 2010; Özbek, 2005). Anglo-Amerikan hukukunda ortaya çıkan resmi arabuluculuk yöntemi için alternatif uyuşmazlık çözümü (Alternative Dispute Resolution-ADR ) tanımı kullanılmış olup hızla yayılan uygulama 2000'lerin başında Türkiye'de de resmi hukuka dâhil edilmiştir.

Saxon (2018: 14-16), enformel arabuluculuğu anlamak için dayandığ́ ideolojileri anlamak gerektiğini anlatmaktadır. Yazar, bireyselci ideoloji (individualist ideology) ve ilişkisel ideoloji (relational ideology) üzerinden toplumlardaki çatışma çözme dinamiklerini analiz etmektedir. Yazara göre, 250 y1llık bireyselci ideolojiye sahip batı kültüründe sorunlar bireysel olarak görüldüğü için çözümler de bireysel olmaktadır. Bu durum günümüz hukuk sisteminde de etkisini göstermektedir. Bireyselci ideolojinin toplumsal çatışmaları çözmeye yetmediğini aktaran yazar, son yirmi yıldır doğu kültüründe etkili olan ilişkisel ideolojinin batı kültüründe de yer edindiğini ifade etmektedir. Doğu kültüründe bireysellikten ziyade grup bağları ön planda olduğu için problem çözme yöntemi olarak enformel arabuluculuk gelişmiştir. Yassine- Hamdani ve Pearson (2014: 23-24), arabulucunun üç özelliğine vurgu yapmaktadırlar. Bunlar, tarafların perspektiflerine karşı tarafsızlık, tarafların anlaşmaya varmalarını sağlayacak şekilde onlara yaptırım uygulama ve arabulucunun konumunu belirleyen statü'dür. Bercovitch ve Rubin (1992) ise arabulucunun prosedür stratejilerini üç başlık altında toplamışlardır. Bunları, tarafların anlaşma yapmalarını sağlayacak şekilde onları etkilemesi için yönlendirici stratejiler, tarafların anlaşmadan doğacak kar-zararı anlamalarını sağlayacak önemli/asli stratejiler ve arabulucunun anlaşmanın denetleyicisi veya garantörü olmasını sağlayacak denetleyici stratejiler şeklinde tanımlamışlardır. Ulutaş (2015: 32), Toplumsal Bir Tip: Kanaat Önderi isimli doktora tezi çalışmasında kanaat önderlerini güven veren, cesur, çabuk karar verebilen ve en doğru kararı vermede ustalaşmış kişiler olarak tanımlamaktadır. Yazara göre, kanaat önderlerinin en belirleyici özelliklerinden biri toplum tarafından önderlik ve dolayısıyla arabuluculuk yapacaklarına olan güven ve inançtır. Yılmaz (2012: 10-12), arabulucuları toplum tarafindan saygı duyulan, çoğunlukla yaşlı ya da iyi 
eğitimli genç, ekonomik gücü bulunan ve toplumsal statüsü yüksek olan kişiler olarak tanımlamaktadır.

Resmi arabuluculuk ile karşılaştırılabilmesi için günümüzde aktif olan enformel arabuluculuk yöntemi çatışma çözümünde adalet olgusu tartışmaları ile birlikte ele alınmıştır. Çatışma çözümünün temelinde tarafların adalete ulaşması vardır. Birey adaletsiz bir durumla karşı karşıya kaldığında hedefteki kişiye karşı yaptığı bütün şiddet eylemlerini meşrulaştırmakta ve sosyal adaletsizliği giderme zorunluluğu olarak görmektedir (Frydenberg, 2005: 131-133). Deustch (1985), çatışmayı anlamak için geliştirdiği adalet teorisi'nde adaletsizliği çatışmanın kaynağı olarak görmektedir. Adaletsizlik çatışmaya neden olduğu gibi adaleti sağlamayan bir çözümde çatışmanın daha fazla derinleşmesine neden olacaktır. Onarıcı adalet kavramı, amaçların, değerlerin, ruhani inançların, sosyal adalet topluluklarının ve yaşam şekli tercihlerinin kriminal adalet sürecinde etkili olması olarak tanımlanmaktadır (Johnstone, 2003). Enformel adalet küçük ölçekli, feodal bağların güçlü olduğu toplumlarda ortaya çıkmıştır (Zehr, 1990). Enformel adalet ile toplumun üyelerinin ihtiyaçlarının giderilmesi ve yaşamlarının geliştirilmesi sağlanır. Bu bağlamda enformel adaletle bireylerin sorunlarının çözülmesinin ötesinde toplumsal çatışma çözümü sağlanmaktadır (Woolford ve Ratner, 2008: 15).

Enformel hukukun resmi olarak tanındığı Güney Afrika'da 2005'de enformel hukuk aktörleri olan 800 geleneksel lider de resmi olarak tanınmıştır. Resmi hukuk Afrika toplumları tarafından sömürgecilik ve onların tepeden inme hukuk sistemleri ile özdeşleştirildiği için enformel hukuk sisteminde kopmadıkları görülmektedir. Post-koloniyal toplumlarda enformel hukukun resmi hukuka entegre edilmesi süreci enformel hukukun resmileşmesi açısından önemli görülmektedir. Sierra Leone'de 149 şeflik bölgesinde bulunan 300 yerel mahkemenin evlenme, boşanma, miras ve arazi kirası gibi davalara bakma yetkisi anayasa tarafından güvence altına alınmış yani enformel hukuk uygulamaları resmileştirilmiştir. Afrika ülkelerinde giderek artan geleneksel hukukun resmi hukuk sistemine dahil edilmesinde var olan bir sorun değişen hükümetler ile politikaların da değişebilmesi ve enformel hukuku yasal olarak gören bir hükümetten sonra gelen diğer hükümetin düzenlemeyi lağvetmesi şeklinde olmaktadır (Chirayath ve diğ., 2005).

Formel hukuk ve enformel hukuk tartışmaları incelendiğinde, Fitzpatrick (1995), enformelformel ayırımını eleştirirken enformel adalet sanki ikinci sınıf bir adalet sistemiymiş ve devletin koruduğu formel adalet sistemi birinci sınıfmış gibi algılanmasına sebep olduğunu savunmaktadır. Yazar, aslında formel-enformel ayırımı yapılmasına karşı çıkıp bu durumun enformel adaletin kötülenmesine neden olduğunu aktarmaktadır. Enformel adalet yapılanmaları Habermas'ın kamusal alanda yer alan "iletişimsel eylem teorisi" (the communicative action theory) ile örtüşmektedir. Enformel adalet ile toplumda ideal olarak yürütülecek prosedürler ile karşılıklı gelişim ve anlayışın sağlanması amaçlanmaktadır. Habermas'a göre enformel adalet ile toplumda sivil kanunlaştırma sağlanabilir. Toplumda 
kamusal aktörlerin çevrelerindeki dünyayı etkileme girişimlerinden biri sayılan enformel adalet ile sivil kanunlaştırma gelişebilir. Enformel adalet resmi adalet üzerinde bir etki yaratarak kendi alanını da genişletebilir ve geliştirebilir. Böylece enformel adaletin, enformel kamusal alandaki pratikleri ile kutsal hukukun toplum üzerindeki etkileri kırılarak, toplumun içindeki çatışmalara kollektif çözümler üretmesi sağlanabilir (Habermas, 1999). Arabuluculuk ile ilgili literatürdeki tartışmalar Deutsch (2001)'un işbirliği ve rekabet, Habermas (1989)'1n bilinçli demokrasi ve dağıtıcı adalet, Kriesberg (1973)'in sosyal çatışmların sosyolojisi, Bush ve Folger (2005)'ın çatışmanın dönüştürülmesi teorisi, Saxon'un dönüştürücü arabuluculuk, Lederach (2005)'ın çatışma çözümünde devlet dışı aktörler çalışmalarından yola çıkılmış ve alandaki temel tartışmalar eleştirileri ile birlikte incelenmiştir. Böylelikle çatışma çözümünde arabuluculuk ve adalet tartışmalarının kavramsal çerçevesi oluşturulmuştur.

\section{İslami Kültürde Enformel Arabuluculuk Yöntemi ile Barıştırma Geleneği}

İslami kültürde çatışma ve barış kavramları Batılı ve Doğulu teorisyenlerin karşılıklı eleştirileri doğrultusunda ele alınmıştır. Özellikle bazı Batılı teorisyenler (Huntington, 2002; Toft, 2007 gibi) İslamiyet'teki cihat anlayışından ve İslam dünyasında var olan çatışmalardan yola çıkarak İslamiyet'i çatışmanın kaynağı olarak görürken Doğulu ve bazı Batılı yazarlar (Abu-Nimer (2001, 2004, 2006, 2011; İrani, 1999; Saxon 2018; Funk ve Said, 2009; Kadayıfçı-Orellana, 2010; Nadia, 2006; Yassine- Hamdani ve Pearson, 2014 gibi) ise İslami kaynaklarda barışa vurgu yapıldığını ve İslami kültürdeki barıştırma geleneği olan sulh girişimlerini İslamiyet'in kaynağında barış olduğuna örnek vermişlerdir. Uzma, dinlerin çatışma çözümündeki rollerinde içlerinde barındırdıkları uyum ve barışın etkili olduğunu; zengin dinî ritüeller ve sembollerin insanlara sağladığı birbirini anlama, kabul etme ve saygı duyma özelliklerinden faydalanılarak taraflar arasında diyaloğun ve uzlaşmanın sağlanabileceğini belirtmektedir. Yazar bu yüzden, sadece batı-merkezli çatışma çözümü yöntemleri ile yetinilmeyip çatışmaların yaşandığı yerlerdeki yerel dinî liderlerden faydalanılması gerektiğinin altını çizmektedir (Uzma, 2011, 58-60). İslamiyet'in kaynağında cihat mı yoksa sulh mu olduğu tartışmaları incelenmiş ve İslami kültürde barıştırma geleneği olan sulha yöntemi derinlemesine araştırılmıştır. Appleby (2000, 256), İslam'ın barışı sağlama kapasitesinin politik liderlerin dini liderlere ve dini entelektüellere sağladıkları meşru hukuk ortamına göre değiştiğini belirtmektedir. Kaya (2013, 17), İslami kültürün etkili olduğu Osmanlı İmparatorluğunda ve devamında Türkiye'de de kolektivist anlayış hüküm sürdüğü için sivil toplum görevi gören dini cemaatler ve kurumların bireysel çatışmaların çözümünde etkili rol oynadıklarını belirtmektedir. Yılmaz (2005), resmi hukukun batı ülkelerinden ithal edildiği Müslüman toplumlarda İslam kültürü resmi hukuka eklemlenmediği için çatışmaların çözümünde enformel İslam hukukun etkili olduğunu aktarmaktadır.

İslami kültürde sulh arabulucunun etkili olduğu, toplumda harmoni ve onurun/şerefin restore edildiği ve toplumun çatışmanın bittiğinden haberdar edildiği çatışma çözme yöntemidir (Saxon, 2018, 2). Kuran'da sulh/barış tarafların arasında yapılabilecek en üst değer eylemi olarak görülmektedir (Aquino, 2008, 180). Arap-İslam bağlamında çatışma çözümündeki kavramlar "wasta" arabuluculuk, "sulh" barıştırma ve "musalaha" uzlaştırma olarak 
tanımlanmaktadır. Çatışma çözümünde etkili olan İslami değerler şöyle sıralanmaktadır: adalet, sosyal güçlendirme, insan hayatının mukaddesliği, bilgi ve neden, yaratıcılık ve yenilik, affetme, kişisel sorumluluk ve tercih, sabr (sabretme), işbirlikçi hareket ve dayanışma, kapsamlılık, çoğulculuk ve çeşitlilik (Uzma, 2004, 59-67). Sulh süreci kan davasından kaçınmanın göstergesi olarak tanımlayan Rohne (2006, 189-190), sulh girişimi ile mağdur tarafın intikam almasının engellendiğini ve böylece fail tarafa güvenli ortam sağlandığını aktarmaktadır.

Özellikle Afganistan'daki Jirga sistemi ve Filistin'deki Wiam sistemleri enformel arabulucuların mikro çatışma çözümünde oynadıkları rolleri gösteren ve Türkiye örneğine de benzeyen vakalar olarak karşımıza çıkmaktadır. Afganistan'da merkezi hükümeti temsil eden şeri hukukun Afganistan'ın bazı doğu ve güney bölgelerinde hiç kullanılmadığı ve buralarda geleneksel enformel hukuk sisteminin etkili olduğunu belirtmektedir. Peştun köy ve kabilelerinde Jirga/Maraka olarak adlandırılan enformel hukuk sistemi Peştun-olmayan Afganlarda Şura adıyla tanımlanmaktadır. Jirga heyeti adam öldürme gibi ağır ceza davalarının çözümü ile ilgilenen o bölgenin en ileir gelenlerinden oluşurken, Maraka heyeti daha küçük ölçekli davalarda başvurulan toplumda saygı duyulan diğer kişilerden oluşmaktadır. Peştu dilinde "halka" anlamına gelen jirga kelimesi Farsça 'da da aynı anlamda kullanılmaktadır. Köyün/kabilenin büyüklerinin halka şeklinde oturarak yerel çatışmaların çözümü için görüştükleri geleneksel hukuk otoritesini temsil eden sistem bu yüzden Jirga olarak tanımlanmaktadır. Jirga sisteminde taraflara ateşkes teklifinde bulunan ve af dileme ile affetme süreçlerini takip eden Nanawate (arabulucu) adında bir heyeti bulunmaktadır (Wardak, 2002, 2004).

Filistin toplumunun mikro-çatışmalarının \%98'ini resmi mahkemelere başvurmadan enformel hukuk ile çözdüklerini belirten arabulucular, resmi hukuk kurumlarına olan güvensizliğin bunda etkili olduğunu belirtmedirler. Filistin toplumunun İsrail mahkemelerine olan güvensizliklerinin geleneksel hukuk yöntemlerine daha fazla talep olmasında etkili olduğu belirtilmektedir. Arabulucuların sulh sürecinde tamamen gönüllü olarak yer aldıkları ve hiçbir maddi karşılığı olmadığı gibi yaptıkları işi doğal olarak gördükleri görülmektedir. İslami kaynaklara referans yapan arabulucular "Allah rızası için” sulhun sağlanmasına yardım ettiklerini belirtmektedirler. Resmi mahkemelerde adaleti aramanın çok pahalı ve uzun bir süreç olması da enformel arabuluculuğun Filistin'de tercih edilmesinde ve toplum tarafindan "alternatif mahkeme" olarak görülmesinde etkili olmaktadır. Mahkemelerin 3-10 yıl arasında sürdügü hatta on yıllardır süren davaların olduğunu belirten Wi'am Merkezi arabulucuları enformel arabuluculuk ile sulhun çok kısa bir sürede en fazla birkaç ay içinde sağlandığını belirtmektedirler. Mikro-çatışmalarda gönüllü olarak yapılan arabuluculuk eylemleri için arabulucuların bazıları ceza alıp hapishanede yattıklarını belirtmektedirler (Saxon, 2018, 98103; Wi'am). Her ne kadar Türkiye şer'i hukukla yönetilmiyor olsa da Kürtlerin yoğun olarak yaşadığı bölgelerin Türkiye'nin geriye kalanı gibi kendini yüzde 90 oranlarında dindar olarak tanımladığı (Çarkoğlu, 2009) için İslami kültürün etkili olduğu bilinmektedir. Bundan dolayı da Ortadoğu coğrafyasında bulunan çatışma coğrafyasının diğer İslami kültürlerde uygulanan enformel sulh yöntemleri ile karşılaştırılması önemli görülmüştür. 


\section{Türkiye'de Arabuluculuk Uygulamaları}

Türkiye'de 2000'lerin başında yasal düzenlemelerin yapıldığı ve 2010'ların başında uygulanmaya başlanan Türk ceza ve ceza muhakemesinde uzlaştırma ve arabuluculuk uygulamalarına ülkede uygulanan enformel arabuluculuk ile kıyaslanabilmesi ve neden halen enformel arabuluculuğa gerek duyulduğunun anlaşılabilmesi açısından önemli görülmüştür. 2000'li yılların başlarında Avrupa Birliği ile gelişen ilişsilerin etkisi ile Türkiye'de de uzlaştırmanın resmi hukuka entegre edilmesi ile ilgili çalışmalar başlamış olup, 2006 yılında uzlaştırma ile ilgili yasal düzenlemeler yapılmış ama sonrasında yapılan değişiklikler ile ancak 2013'ten sonra bu yöntem arabuluculuk ismi ile uygulanmaya başlanmıştır (Öztürk, 2016). Alternatif uyuşmazlık çözüm yöntemleri incelendiğinde en fazla başvurulan yöntemin arabuluculuk olduğu görülmektedir. Üçüncü bir kişinin arabulucuğunda tarafların ortak uzlaşma için çözüm ürettikleri bu yöntemi enformel arabuluculuktan ayıran en önemli noktası varılan anlaşma belgesinin mahkeme tarafından resmî belge olarak kabul görmesidir. Ayrıca arabuluculuk süreci mahkemeler tarafında davanın taraflarına zorla uygulanamayıp tamamen tarafların ikisinin de gönüllü katılımlarına bağlıdır. Ayrıca, taraflar uzlaşmaya varamadıkları noktada arabuluculuk girişimi sona erdirilip dava tekrar mahkemeye intikal etmektedir. Bu yöntemin diğer bir önemli noktası ise sürecin hak değil menfaat temelli olmasıdır. Her iki tarafın kazan-kazan şeklinde anlaşması amaç edinilmektedir (Öztürk, 2016; Kekeç, 2010).

Türkiye'de resmi arabuluculuk sistemi son on yılda geliştirilmiş ve Batı modeli alınarak tasarlanmış olsa da aslında Anadolu topraklarında enformel arabuluculuk yönteminin çok daha eskilere dayandığı görülmektedir. Kaya (2013), Klasik Osmanlı sisteminde bulunan "Kethüdalık" kurumunun enformel hukuktaki rolüne değinmektedir. Yazar, her yerleşim birimi, dini veya etnik cemaatin kendi kethüdasını seçme hakkına sahip olduğunu ve aşiret beylerinin de kethüda olarak kabul edildiğini aktarmaktadır. Osmanlı sosyal yaşamında aşiretlerin kendi içlerindeki ve diğer aşiretlerle olan anlaşmazlıkları bu kurum üzerinden çözülmekteydi. "Arfelik/Ariflik" olarak tanımlanan bu hukuk sisteminde Arap aşiretlerinde geleneksel hukuku şifahi olarak öğrenip davaların çözümünde uygulayan kimselere "Arfe" denilmekteydi. Aydın (2016, 183-185), Osmanlı döneminde Çankırı ve Kastamonu bölgesinde yaşayan insanların kendi aralarındaki uyuşmazlıkların çözümü için mahkemelere başvurmamalarının nedenleri olarak alternatif çözüm yollarının varlığı, dava açmanın masrafları, yoksul ve zayıfa karşı olan ayrımcılık maddelerini sıralamaktadır.

Türkiye'de enformel arabuluculuk güvenilir, saygın, adil ve statü sahibi olduğuna inanılan kanaat önderleri olarak tanımlanan bireyler tarafından uygulanmaktadır. Ulutaş (2015) kanaat kavramını "kani kılma" ve "kanaat getirme" kavramları üzerinden açıklayıp kanaat kelimesinin "ikna” kavramı ile birlikte düşünülmesi gerektiğini belirtmektedir. Şimşek ve Fidan, dışarıdan herhangi bir müdahale olmadan meydana gelen toplumun "organik liderlerine" değinmektedir. Yazarlar, organik liderin yönetici tarafından seçilmeyen grubun yarattığı liderler olduğu için içinden çıktıkları toplum üzerinde yasal liderlerden daha fazla 
etkili olduklarını açıklamaktadırlar (2005, 65). Türkiye'de saha çalışmasının yapıldığı coğrafyada enformel arabulucuların rollerinin anlaşılabilmesi için bölgede hakim olan aşiret yapısı ve kan davası gibi olguların incelenmesi gerekmektedir. Toplumda suç ve ceza için uygulanan kolektif sorumluluk ilkesi tartışılmadan enformel arabulucuların mikro çatışma çözümünde neden resmi mahkemelerden daha etkili olabildikleri anlaşılamayabilir. YalçınHeckmann $(2012,133)$, aşiret örgütünün en alt birimi olarak "mal” denen ve haneyi paylaşan ortak akraba grubunu görmektedir. Mal ayrıca sülale anlamında da kullanılmaktadır. Van Bruinessen, (2002, 2003) her ne kadar Türkiye ve İran'da devletlerin Kürt toplumundaki aşiret yapısını bozmak için ağalık sistemini engellemiş olsa da toplum içindeki aşiret yapısı ve etkisinin engelleyemediklerini aktarmaktadır. Ulutaş (2015, 60-69), Kürtlerin sosyal morfolojisinin anlaşılmasında aşiretlerin başat role sahip olduklarını ve Kürtlerin sosyal ve siyasal yapıları ile ilgili yapılacak çalışmalarda aşiret yapısının göz ardı edilmesi durumunda eksiklik olacağını vurgulamaktadır. Yazar, karar alma süreçlerinde bir istişare görevi gören ve "Ru Spi" olarak adlandırılan "ihtiyar heyetinden" bahsetmektedir. Bu heyetin aldığ kararların aşiretin bütün mensupları tarafından bağlayıcı olduğunu açıklayan yazar, özellikle kan davaları, kavgalar ve namus davalarında kolektif bilinçle refleks verilmesinin beklendiğine vurgu yapmaktadır. Ökten "Kan Davası: Kanın Öcü ya da Şeref Uğruna Verilen Kolektif Savaş" (2010, 168-172) isimli makalesinde "kan gütme" ve "kan intikamı" olarak isimlendirilen olgunun Türkiye'de "kan davası" olarak tanımlandığını ve olgunun temelinde öç almanın bulunduğunu belirtmektedir. Bir çatışmanın kan davasına dönüşmesinde onur ve şeref olguları etkili olmaktadır. Toplum içinde saygı duyulmanın kaynağı olarak onur ve şerefe sahip olmak kabul edildiği için aileden birisine yönelik bir saldırı toplumdaki saygınlığın kaybedilmesine neden olarak görülmektedir. Ulutaş $(2015,95-99)$ onur ve şeref kavramlarının toplum tarafından bireylere empoze edildiğini ve toplum tarafından kutsanan bu kavramlara bireylerin söz verirken namusum ve şerefim üzerine diyerek yemin etmelerini örnek olarak vermektedir. Ökten $(2010,170)$, kan davası vakalarında grubun bireylerinden birine karşı yapılan saldırının grubun onuruna yapılmış bir saldırı olarak kabul edildiği için grubun bütünün "kirlenmiş" gibi hissettiği için öcün alınması ve yere dökülen "kanın temizlenmesi" gerektiği saikiyle hareket edildiğini aktarmaktadır. Yazarın "kolektif sorumluluk ilkesi” olarak açıkladığı bu durumda toplumda bireysellik ön planda olmadığı ve grup ön planda olduğu için ortak hareket etme zorunluluğu olduğunu belirtmektedir.

\section{Diyarbakır'da Enformel Arabulucu olarak Rusipîlerin Barıştırma Geleneği}

Öncelikle coğrafyada çatışma çözümünde rol alan enformel arabulucuların kimler olduğu incelenecektir. Bundan sonraki kısımlarda aktarılan veriler araştırmacının yaptığı görüşmeler ve gözlemlerine dayanarak elde edilmiştir. Türkiye'de kanaat önderi olarak kullanılan kavrama karşılık sahada rusipî (aksakallı, ak yüzlü) kavramının kullanıldığı görülmüştür. Rusipî kavramı çatışmalarda arabuluculuk yapan kişileri tanımlayan geleneksel bir kavram olarak bazı çalışmalarda da karşımıza çıkmaktadır (Bruinessen, 1991; Ünsal, 1995; Ulutaş, 2015). Sahada bu kavram kullanıldığı için araştırmada da bu kavram kullanılmıştır. Rusipî imam (Bakırcı, 2014), şeyh ve mele gibi dini bir figür ya da muhtar, belediye başkanı, parti temsilcisi gibi yerel bir yönetici; ağa, aşiret reisi, aile büyügü gibi geleneksel bir lider (van Bruinessen, 2010; Kaya 2013) ya da öğretmen, doktor, çiftçi gibi bir meslek grubundan 
(Ulutaş, 2015) olabilmektedir. Rusipînin kim olduğu, özellikleri ve çözüm yöntemlerinin neler olduğunu araştırılmıştır. Yapılan görüşmelerde rusipînin en belirgin özelliklerinden birinin kullandığı dil ve uslüp olduğu görülmektedir. Yumuşak dilin önemine değinen görüşmeciler ancak bu şekilde tarafların ikna edilebileceğine vurgu yapmaktadırlar. Yumuşak dil başlangıç için önemli iken sonrasında "büyük" olarak kabul edilen arabulucunun sert bir dil kullanması da doğal karşılanmaktadır. Dil dışında önemli olan diğer bir özellik de yardımsever olmaları ve yardım ederken bir çıkar ya da beklentilerinin olmamasıdır.

Bölgedeki makro çatışma olan Kürt meselesinin toplum içindeki mikro çatışmaların çözümünde toplumun bakış açısını etkilediği görüldüğü için toplumun rusipîlere başvurmalarının nedenleri araştırılacaktır. Geleneksel arabulucular olan rusipîlere başvurulmasının nedeninin gelenek mi yoksa devlete yönelik bakış açısı kaynaklı bir tercih mi olduğunu sorgulanmıştır. Bölgede etkili bir gelenek olan kan davası vakaları coğrafyadaki suç ve cezanın kollektifliğini gözler önüne sermektedir. Bundan dolayı resmi mahkemeler yerine rusipîler aracılığıyla yapılan barışın çatışmanın çözümü için daha etkili ve güvenilir bir geleneksel yöntem olduğu kabul görmektedir. Çatışmanın çözümü için rusipîlere başvurulmasının nedenini geleneksel bir yöntem olması ile açıklayan görüşmeciler "kendimizi bildik bileli bu şekilde davalar çözülüyor” cümlesi ile özetlemektedirler. Görüşmecilerden bazıları ise resmi mahkeme yerine rusipîlere başvurulmasının nedeni olarak geleneksel bir yöntem olmasındna ziyade devlete ve hukuk sistemine olan güvensizliğe bağlamaktadırlar. Enformel arabuluculara başvurulmasının nedeni olarak devlete ve kurumlarına olan güvensizliğin yattığını belirtenlerin arasında HDP/DBP Halkla İlişkiler Komisyonu'nda yer alan kişiler ağırlıklı olarak yer alsa da köylerde görüşülen ve kendilerini bağımsız olarak tanımlayan rusipîlerden de bu görüşü savunanlar mevcuttu. Bazı görüşmeciler de arabuluculara başvurulmasının sadece geleneksel bir yöntem olması ya da devlet ve resmi kurumlara olan güvensizlikle açıklanmasının yetersiz kalacağını ve her ikisinin de etkili olduğu savunmaktadırlar.

Rusipîlik yöntemine çatışmanın hangi tarafının başvurduğu ve barışı isteyen tarafın fail mi yoksa mağdur taraf mı olduğu araştırılmıştır. Bu soruya farklı kişiler tarafından farklı cevaplar verilse de aslında barış için çağrıda bulunan tarafın çatışmanın türüne göre değişkenlik gösterdiği görülmektedir. Kız kaçırma olaylarında da arabuluculuk için başvuruda bulunan taraf erkeğin ailesi olmaktadır. Yine kız tarafının kendilerinden intikam almak için onlardan birinin kızını kaçırması ya da öldürme girişiminde bulunması tehdidine karşılık erkeğin ailesi ivedilikle barışmak için arabuluculara başvurmaktadır. Öldürme ve yaralama gibi kan davasına evirilebilen çatışmalarda arabuluculuk çağrısı yapan taraf "fail" olarak tanımlayabileceğimiz suçlu taraf olmaktadır. Burada suçluluk oranı hangi tarafın zafiyetinin fazla olduğu ile ölçülmektedir. Mesela bir çatışma da bir taraftan bir kişi diğer taraftan iki kişi hayatını kaybetmişse fail olan taraf iki kişinin ölümüne neden olan taraf olarak görülmektedir. Fail tarafın bir an önce barışın sağlanması için arabuluculuk için başvurmasının nedeni karşı tarafın intikam almasından duyulan korkudur. Bazı görüşmeciler de mağdur tarafın barış için 
arabuluculara başvurduğunu çünkü ya intikam alacak kadar gücü olmadığını ya da daha fazla zülme uğramaktan korktuğunu aktarmaktadırlar. Mağdur tarafın çözüm istemesinin bir nedeni de öldürme davalarında intikam almaya gücü yetmeyen ya da bunu istemeyen kişinin "köyden kalkmak" olarak tanımlanan şekilde evini oradan götürmesi geleneğinin bulunmasıdır. Diğer bir çatışma türü olan işçi-işveren arasındaki alacak verecek çatışmalarında hakkını alamadığını için işçi çözüm için başvuruda bulunurken genellikle işveren arabulucular ile görüşmekten kaçınmaktadır. Parasını faiz için yerel tefecilere veren kişiler de paralarını anlaştıkları faizi ile alamadıkları için arabuluculara başvuruda bulunmaktadırlar. Alacakverecek çatışmalarında alacaklının çözüm için fedakârlık yapmak zorunda kaldığı görülmektedir. Verecekli bütün borcunu imkânı olmadığını öne sürerek ödemeyi reddettiği için arabulucularda daha düşük bir meblağa tarafları ikna etmeye çalışmaktadırlar. Bütün çatışma türlerinde çözüm için taraflardan birinin ama genellikle mağdur tarafın fedakârlık yaptığı aktarılmaktadır.

Çatışma türüne göre başvuran tarafın değiştiği görüldüğü için toplumda enformel arabulucular aracılığıyla çözülen ve "dava" olarak tanımlanan çatışma türlerinin neler olduğu incelenmiştir. Bölgede öldürme/yaralama/kan davası başta olmak üzere, kız kaçırma, aile içi çatışmalar, arazi çatışmaları, alacak-verecek çatışmaları dışında bir de birden fazla türün iç içe geçtiği ve araştırmacının karma çatışmalar olarak tanımladığı vakalarda rusipîlere başvurulduğu görülmüştür. Çözümü için arabuluculara başvurulan mikro çatışmalar hangileridir diye sorulduğunda toplum içinde "dava" olarak nitelenen ve iki aile ya da iki birey arasında meydana gelmiş olan ama sonuçları ve sorumluluğu itibariyle bütün aileyi ilgilendiren öldürme, kan davası ya da yaralama çatışmaları birincil sırada sayılmıştır. On yıllardır süren kan davaları ile ilgili barıştırma girişimleri bulunduğu gibi birkaç yıldır meydana gelmiş kan davaları ya da henüz tek bir taraftan birinin hayatını kaybettiği ve kan davasına dönüşme tehlikesi bulunan davalar da yer almaktadır. Adam öldürme ve yaralama olaylarında mağdur tarafın barışması için failin tarafın "cirm” (bedel) ödemesi gerektiği ve bunun da "heqê xwenî" (kan parası) olarak tanımlandığı görülmektedir. Kan parası belirlenirken arabulucular tarafından mağdur ve fail tarafın maddi durumu, mağdur tarafın kaybı, fail tarafın ödeme gücü, fail tarafın ailesinin verebileceği maddi destek ve "hayırseveler"in verebileceği destekler gibi göz önünde bulundurulan bazı faktörler vardır. Ayrıca belirlenen kan parası miktarının benzer vakalar için caydırıcı olması da önemli faktörlerden biridir. Görüşmeciler kan parasının İslamiyet’ten beri uygulanan bir gelenek olduğu ve barış için fail tarafın ödemesi gerektiğini savunmaktadırlar. Failin maddi durumu buna imkân vermiyorsa da kolektif sorumluluk bilinci gereği fail tarafın ailesi bu sorumluluğu yüklenmek durumunda kalmaktadır. En fazla çözüm için başvurulan davaların ikinci sıralamasında "kız kaçırma" olarak tanımlanan; evlenmek niyetiyle bir kadının kendi rızası ile ya da rızası olmadan kaçırılması vakaları gelmektedir. Kız kaçırmanın evlenme niyetiyle olması önemli zira görüşmecilerden hiçbir kişi ya da kurum başka amaçlarla kız kaçırma davalarında aracılık yapmadıklarını ve bunun kırmızıçizgileri olduğunu belirtiler. Kadınların çatışmanın tarafı olduğu diğer bir mikro çatışma türü ise aile içi çatışmalar başlığı altında toplanabilir. Bu başlığın altında aile içi şiddet, aile büyükleri ile anlaşmazlık yaşama, 
boşanma gibi pek çok alt başlık yer almaktadır. Geniş aile kültürünün yer aldığı toplumda evlenmek gibi boşanmak da iki birey arasında gerçekleşen bir eylemden ziyade iki aileyi de ilgilendiren kolektif bir eylem olarak görülmektedir. Boşanmanın ailenin onurunu zedeleyici olarak görüldüğü toplumda eşler arasında sorunlar olsa da aileler genellikle boşanmalarına razı olmamaktadır. Aile içi çatışmalarda genelde mağdur konumunda olan kadının enformel arabuluculara başvurduğu ve yardım istediği görülmektedir. Bu yardım talebi erkeğin şiddet uygulamaya son vermesi, ailesinin ekonomik ihtiyaçlarını gidermesi, aile ile yaşanıyorsa ayrı eve çıkması gibi sebeplerden ötürü "uyarılması", "kulağının çekilmesi”, "nasihat edilmesi" veya "gözünün korkutulması" gibi taleplerle yapılmaktadır. Diğer bir mikro çatışma türü ise "arazi meselesi” olarak tanımlanabilecek olan sınır çatışmalarıdır. Arazi çatışmalarının çoğunun kaynağında tapusuz olan ve herkesin kime ait olduğunu bildiği arazilerin tapu kadastro memurlarının kayıt altına alma sürecinde meydana geldiği görülmektedir. Tapu kadastro memurları sınır çizimleri için köy köy ilerledikleri için, bazı kişilerin komşu köyün arazisini kendi arazisi olarak kaydettirip tapu aldığı görülmektedir. Bunun sonradan fark edilmesi ile komşu köylüler ya da aynı köyden kişiler arasında arazi meselesinden dolayı çatışmaların yaşandığ 1 aktarılmıştır. Her ne kadar çatışmaların çoğunluğunun kırsal kökenli olduğu düşünülse de köyden kentlere göç ile birlikte hizmet sektöründe çalışan işçiler ile işverenleri arasında meydana gelen "alacak-verecek" meseleleri de diğer bir artan çatışma türünü oluşturmaktadır. Özellikle inşaat sektöründe taşeron müteahhit ile işçi arasında alacak verecek sorunlarının sık meydana geldiği görülmektedir.

Geleneksel bir barıştırma yöntemi olarak tanımlanan rusipilik yönteminde arabulucuların hangi kurallara göre çatışmaları çözdükleri önemli bir soru olarak görülmektedir. Bu soruya yanıt alabilmek için araştırmada rusipîlik hukuku diye tanımlanan hukuki normlar öğrenmeye çalışılmıştır. Görüşmecilerin "huquqa nasa" (toplum hukuku) olarak tanımladıkları hukuk kurallarının örf, adet, gelenek, şer'i hukuk ve benzer vakalarda verilen kararların karışımı şeklinde olan toplumsal kurallar olduğu görülecektir. Ceza, medeni ve ticaret hukukunun alanlarına giren çatışmaların çözümünde uygulanan kuralların genel geçer olmadığı ve pek çok faktöre bağlı olarak vakadan vakaya değişebildiği görülmüştür. Bir çatışma meydana geldiğinde taraflardan ya da çevreden biri arabuluculuk yapması için öncelikle o bölgede etkili olan rusipîlere başvurmaktadır. Davanın tarafları açısından saygın, adil ve objektif olarak kabul edilen rusipîlerin çağırılması sürecin kilit noktasını oluşturmaktadır. Rusipîlerden meydana gelen arabulucular bir heyet şeklinde taraflar arasında onları barıştırmak için görüşmelere başlamaktadır. Görüldüğü üzere sabit bir mahkeme mekânı olmamakla birlikte, davanın tarafları, davayı araştıran ve karara bağlayan bir rusipî heyeti bulunmaktadır. Nihai amaç barışın sağlanması olup mağdur tarafin zararının tazmini için davanın türüne göre "cirm" olarak adlandırılan "bedel" ismi altında çeşitli cezalar ödenmektedir. Yani dava sonucunda cezai bir yaptırım da görülmektedir. Araştırmanın amacı enformel arabuluculukla çözülen vakaların sayısını ortaya çıkarmak olmadığı ve niceliksel olarak bu zor olduğu için görüşmecilerin aktardıkları vaka örnekleri üzerinden rusipîlik sistemi öğrenilmeye çalışılmıştır. 


\section{Günümüzde Enformel Hukuk Aracı Olarak Rusipîliğin Yeniden İnşası}

Saha bulgularında çatışmaların yüzde seksen-doksanlarda bölgede "Kürt siyasi partileri” olarak betimlenen HDP ve DBP çatısı altında kurulan Halklar İlişkiler Komisyonu (HİK) bünyesinde çözüldüğü ifade edildiği için rusipiliğin siyasi parti bünyesindeki dönüşümü incelenmiştir. Görüşmeciler bu iki siyasi partiyi Kürt siyasi partileri olarak niteledikleri ve onları tanımlamak için "parti” kavramını kullandıkları için araştırmada da aynı ifade kullanılmıştır. Sadece HDP/DBP değil bölgede etkili olan diğer siyasi partilerin çatısı altında da benzer barıştırma girişimlerinin olduğu aktarıldığı için, bölgede en fazla etkili olan 7 siyasi parti seçilmiştir. Seçilen siyasi partilerin "davaların yapılması" olarak aktarılan çatışma çözümündeki rolleri, sahip oldukları sistem, dâhil oldukları çatışma türleri, kırmızıçizgi olarak gördükleri ve dâhil olmadıkları çatışma türleri, sürece dâhil olmadan taraflardan onlara yetki verdiklerine dair aldıkları "irade beyanları" ve çözüm sürecinin sonucunda yaptıkları barış törenleri ayrıntılı olarak incelenmiştir. Siyasi parti üzerinden yaşanan yeniden inşanın anlaşılabilmesi için öncelikle temel aktör olarak görülen HDP/DBP siyasi partilerinin Halkla İlişkiler Komisyonu (HİK) temsilcileri ve siyasi partiye bağlı ya da bireysel olarak arabuluculuk yapan rusipîler ile görüşmeler gerçekleştirilmiştir. Sahada kısaca "parti” olarak tanımlanan Kürt siyasi partilerinden görüşmecilerin aktardıkları verilerin teyit edilmesi ve karşılaştırılması için daha sonra Hüda-par, AKP, CHP, MHP ve Saadet Partisi temsilcileri ile görüşmeler gerçekleştirilmiştir. Ayrıca çeşitli çatışmaların tarafları ile görüşmeler yapılarak çatışma ve çözüm süreçlerini aktarmaları ve çatışma ile barıştırmanın onlar üzerindeki etkileri incelenmiştir.

HDP/DBP partisinin halkla ilişkiler biriminin başında biri mele (imam) biri de parti yöneticisi iki kişi görev almaktadır. Partinin il başkanlığında halkın davalarını çözmek için 8-10 kişilik bir ekip düzenli olarak görev yapmaktadır. Ayrıca Halklar ilişkiler Komisyonu (HİK)'nda da pek çok mele, şeyh ve hacı gibi dini unvana sahipya muhafazakâr kişiler yer almaktadır. Bu sayede halkın içinde kendini muhafazakâr olarak tanımlayan Kürtlerin partiye yönelik eleştirileri de dikkate alınmış olmaktadır. Rusipîlerin geleneksel olarak yaptıkları arabuluculuk girişimlerinin parti çatısı altında nasıl yapıldığ incelendiğinde süreç şu şekilde aktarılmaktadır. Kendilerine davanın tarafları ya da çevreden birisi tarafından yapılan arabuluculuk başvurusu sonrasında Halklar ilişkiler biriminde görevli olan kişiler davanın meydana geldiği coğrafyada ağırlığı olan Rusipîleri araştırıp onlardan en fazla sözü geçen, ağırlığı olan 3-5 kişiyi kurumlarına davet etmektedirler. Zaten bu tür davalarda geleneksel olarak arabuluculuk yapmaya alışık olan rusipîler bu tür çağrılara cevap vermektedirler. Rusipî heyeti öncelikle her iki taraf ile ayrı ayrı görüşerek davada arabulucu olmak istediklerini belirtip onlardan "yetki" istemektedirler. Her iki tarafta barış talebinde bulunup irade beyanı verdikten sonra rusipî heyeti her iki tarafla defalarca görüşerek davayı incelemeye başlamaktadır. Bu noktada sözüne güvenilen şahitler de dinlenerek derinlemesine bir inceleme yapılmaktadır. Rusipî heyeti davayı incelediğine kanaat ettikten sonra taraflara ayrı ayrı verdikleri kararı bildirmektedirler. Verilen karar barışın sağlanması olup bunun için tarafların zararının tazminine rusipî heyeti karar vermektedir. Ayrıca, halkla ilişkiler komisyonunun diğer bir görevi de arabuluculuk görevi gören rusipîler ile iletişim halinde 
olmak ve süreçte herhangi bir tıkanma yaşandığında başka rusipîlerin sürece dâhil edilmesini sağlamak olmaktadır. Diyarbakır'da görev yapan memurların ve çalışanların da çatışmalarını çözmek için partiye başvurduklarını belirttiler. İki avukat arasında meydana gelen bir çatışmayı yargı mensupları olmalarına rağmen çözmek için mahkeme yerine partiye başvurdukları aktarıldı. Ayrıca, zaman zaman polis, jandarma gibi kolluk kuvvetleri personelinin de kişisel çatışma yaşadıkları tarafları uzlaşmaya ikna etmek için partiden destek aldıkları anlatıldı. Çatışmalarda özellikle taraflarda biri yerli ise dışarıdan gelen kişi çatışmayı çözebilmek için arabulucu olarak partiye başvurmaktadır. Çünkü görüldüğü kadarıyla halk arasında partinin arabuluculuk yaptığı davaların nihai olarak çözüldüğüne dair bir alg1 bulunmaktadır. Bundan dolayı korucuların da zaman zaman davalarını çözmek için partiye başvurdukları ama genellikle barış törenlerinin devlet tarafından öğrenilmemesi için kamuya açık yerlerde yapmadıkları aktarılmaktadır. Partiye hangi çatışma türleri için başvurulduğu sorulduğunda; her türden başvuru geldiğini ama kendilerinin kırmızıçizgi olarak belirledikleri çatışmalar dışında hepsinin çözümü için çalıştıklarını aktarmaktadırlar. Parti ikinci eşe karşı olduğu için ikinci eş olarak kız kaçırma davalarına kesinlikle müdahil olmadıklarını aktarmaktadırlar. Ayrıca fuhuş, uyuşturucu, hırsızlık, faiz gibi adi suçların toplumda giderek arttığını ama bunlarda muhatap bulunamadığı için müdahil olamadıklarını belirttiler.

Hüda-Par referans olarak İslam ve Kürt milliyetçiliğini benimseyen partinin halkla ilişkiler birimi kendilerine yapılan başvurular doğrultusunda çatışmaların çözümünde rol aldıklarını belirtmektedirler. Gelen başvuruların kendi tabanlarından olduğunu belirten parti temsilcisi; HDP komisyonundaki ile benzer bir şekilde o bölgede sözü geçen kanaat önderleri aracılığıyla taraflar arasında barışı sağlamaya çalıştıklarını aktarmaktadır. Halk ile iletişim kurma yöntemleri olarak halkın partilerine başvurması dışında cenazeler, taziyeler ve düğünlere katılmaları şeklinde olduğunu belirten temsilci; bir dava için başvuruda bulunulduğunda parti başkanının da kanaat önderi olarak arabuluculuk yaptığını aktarmaktadır. AKP halktan kendilerine gelen arabuluculuk talepleri sorulduğunda Halkla ilişkiler bünyesinde davaları çözen bir komisyon bulunduğunu aktarılmıştır. Barışma süreci tıpkı diğerlerinde olduğu gibi çatışmanın çözümü için bir tarafın başvurması sonucu kanaat önderleri ve davanın büyüklüğüne göre parti yöneticileri, milletvekilleri ya da bakanların arabuluculuk yapması ile tarafların barıştırıldığını aktarılmaktadır. Hükümet partisinin çözdüğü davalarda arabulucuların yerel rusipîlerden ziyade devlet görevlileri olduğu görülmektedir. Ne var ki buna rağmen sonraki kısımda görüleceği üzere gücünü resmi devlet görevlilerinden alan barış her zaman kalıcı barış olmayıp çatışmalar yeniden körüklenebilmektedir. AKP'li temsilci, taraflar arasında barış sağlanmasına rağmen bunun her zaman nihai barış olmadığını ve tarafların yeniden çatışmaya başvurduğu durumların da mevcut olduğunu aktarmaktadır. CHP "İnsan Hakları Komisyonu” adıyla kurulan komisyonda yer alan partililer, yerel STK yöneticileri ve iş adamları ile birlikte kendilerine başvurulan tarafların çatışma çözümünde rol almaktadırlar. Kurul dışında dışarıdan destek alındığında başvurucunun muhafazakâr ya da laik olmasına göre kişiler kurula dâhil edilmektedir. Siyasi parti temsilcisi ilde tabanları fazla olmadığı için kendilerine çok fazla başvuru gelmediğini ama gelen durumlarda yerel rusipîlerden ziyade STK temsilcileri ve iş 
adamları ile birlikte arabuluculuk yaptıklarını aktarmaktadır. Ayrıca kan davası gibi barıştırılması zor davalar kendilerine başvurunun çok nadir geldiğini aktaran görüşmeci genel olarak da çok fazla başvuru almadıklarını ve senede bir iki vaka için başvuru yapıldığını belirtmektedir. CHP siyasi partisi çatısı altında yapılan arabuluculuk girişimlerinde de tıpkı HDP/DBP siyasi partileri gibi müdahil olmadıkları ve kırmızı çizgi olarak tanımladıkları vakaların benzer olduğu görülmektedir.

MHP Diyarbakır'da kendi tabanları az olduğu için bütün ilçelerde şube açamadıklarını ama kendi tabanlarından insanların sorunlarının çözümü için kendilerine başvurduklarını belirtmektedirler. Diğer siyasi partilerde olduğu gibi halkla hasta ziyaretleri, barış, düğün ve taziyeler aracılığıyla ilişki kurulduğu açıklanmaktadır. "her partinin tabanı ona gidiyor" diyen Mehdi kendilerine de ağırlıklı olarak ülkücülerin ve korucuların arabuluculuk için başvurduklarını açıklamaktadır. Başvuran tarafların daha fazla korucu olduklarını ve en fazla kız kaçırma ya da alacak-verecek sorunları için kendilerine başvuru olduğunu belirten Cihat, başvuruların sıklığını sorulduğunda senede ancak bir iki dava için başvuru olduğunu belirtmektedir. Saadet Partisi temsilcisi kanaat önderleri aracılığıyla yapılan çatışma çözümünden sorulduğunda kendilerine bu şekilde başvuruların gelmediğini ve herhangi bir çatışma çözümünde rol almadıklarını belirtti. Enformel arabulucular aracılığıyla yapılan mikro çatışma çözümü zaten geleneksel bir yöntem olduğu için arabuluculuk yapan bütün siyasi partilerin başvurduğu yöntemlerin birbirine benzediği görülmektedir. Özellikle siyasi partilerin bünyesinde yapılan barış törenlerinin hepsinde de dini ritüellere başvurulduğu görülmektedir. Barış töreni ritüelleri geleneksel yöntemin tekrarı olarak düzlenirken siyasi partilerdeki arabuluculuk sisteminin öncelikle HDP/DBP siyasi partileri tarafindan yeniden dönüştürüldüğü ve diğer siyasi partilerin de bazı noktaları ile onları örnek alarak benzer bir sistem kurmaya çalıştıkları görülmektedir. Siyasi partilerle yapılan ilk görüşmelerde HDP, DBP, Hüda-par ve AKP'ye referans aracılığıyla görüşmeler ayarlanırken CHP, MHP ve Saadet Partisi'nde referansa gerek kalmadan görüşmeler gerçekleştirilebilmiştir.

Siyasi partilerin çatısı altında yapılan barıştırmalarda kadınların rollerinin incelenmesi için iki ayrı isim altında "Barış Anneleri" ve "partili kadınlar" olarak tanımlanan grupların rolleri, çatışma ve barış perspektifleri ve diğer arabulucular olan erkeklere karşı eleştirileri tartışılmıştır. Kürt siyasi partileri temsilcileri kadınların da dâhil edildiğini belirtmişlerdir. Diğer siyasi parti temsilcileri ise arabuluculuk yapan komisyonlarında kadınların yer almadığını açıklamışlardır. Parti içindeki erkek görüşmeciler kadınların da çatışma çözümünde rol almaları gerektiğini savunmalarına rağmen bunun kadınların taraf olduğu vakalarda onlarla daha "rahat konuşacakları" için önemsemektedirler. Kan davası, alacakverecek, arazi çatışmaları gibi vakalara kadınların katılımının gerekli görmedikleri gözlemlenmektedir. Hem derinlemesine görüşme yapılan iki barış annesi hem de 7 barış annesinin katıldığı odak grup görüşmesinde kadınlar, barış törenlerinde yer aldıklarını ama kendi deyimleri ile "vitrin" görevi gördüklerini belirtmektedirler. Partinin herhangi bir davanın çözüm sürecine kendilerini dâhil etmediğini ve sadece kamuya açık barış törenleri gerçekleştirildiğinde kendilerinin davet edildiklerini anlattılar. HDP ve DBP'in her halkla ilişkiler komisyonunda en az bir kadın da görev almaktadır. Komisyonda görev alan kadınlar 
dışında partinin içinde kendilerini feminist kadınlar olarak tanımlayan partili kadınların da çatışmanın tarafı kadın olduğunda rol aldıkları görülmektedir. Özellikle kız kaçırma ya da aile içi çatışmalar ile ilgili bir vaka olduğunda çatışmanın tarafı olan kadınlar ile partili kadınlar görüşmektedir. Bunun amacının görüştüğü kişi rusipî bile olsa kadının erkeklere "kendini yeterince anlatamayacağı" ya da "çekinebileceğii" için "kendini rahat hissetmesi" ve anlatması gereken mahrem konular varsa da paylaşabilmesi olarak aktarılmaktadır.

Saha çalışmasının yapıldığı coğrafyada kolektif sorumluluk ilkesinin ne tür yansımaları olduğu ve Rusipîlik yönteminde rastlanan İslami kültürün etkileri incelenmiştir. Suç ve cezanın kolektif olarak görülmesinde dolayı failin bütün akrabaları taraflar arasında barış sağlanmayana kadar kendilerini güvende hissetmemektedirler. Kolektif sorumluluk ilkesinin sadece kötü olarak algılanmaması gerektiği ve bu sayede toplumsal barışın sağlandığını düşünen görüşmeciler de mevcuttur. Özellikle toplumsallık ön planda olduğu için tarafların barıştıktan sonra tekrar şiddete başvurmamalarında topluma karşı duydukları sorumluluk hissini ve bağını etkili olduğu aktarılmaktadır. Mikro çatışmaların çözümünde rol alan rusipîlerin ağırlıklı olarak dini unvana sahip oldukları aktarılmıştı. Bunda toplumda var olan İslami kültürün etkisi olduğ görülmektedir. Bundan dolayı da sol ve seküler çizgide olan HDP, DBP ve CHP enformel arabuluculuk girişimlerinde toplumdaki dini unvana sahip arabulucularla birlikte çalışmakta ve barış törenlerini de yine İslami kültüre göre düzenlemektedir. Bu yüzden rusipîler de tarafları barışa ikna etmek için kullandıkları dilde sıkça Kuran ve Hadis gibi İslami kaynaklara referans yapmaktadırlar. Bunda hem kendilerinin de aynı İslami kültüre sahip olmaları hem de geleneksel olarak büyüklerinden bu şekilde öğrenmeleri etkili olmaktadır. Toplum üzerinde İslami kültür kadar dini liderlerin de etkili olduğu ve bu yüzden Kuran altından geçme dışında din adamlarının da barışmaya ve affetmeye dair vaaz verme ritüelini gerçekleştirdikleri görülmektedir. Tarafların barışması için gerçekleştirilen törende Kuran'ın altından geçme geleneği İslami bir gelenek olup Kürt toplumunda da İslami geleneğe referansla barış törenlerinin bu şekilde düzenlendiği görülmektedir. Muhafazakâr olan toplumda Kuran altından geçen çatışmanın taraflarının kendilerini “Kuran'ın çarpmasından korktukları" için barışı bozmayacaklarına inanıldığı gözlemlenmiştir.

Rusipîlik yöntemi ile yapılan barıştırmanın resmi mahkemelerin yargılama sisteminden farklı olarak taraflar arasında barışı sağladığı görülmekle birlikte barışın kalıcı mı yoksa geçici mi olduğu olduğu sorusuna cevap aranmıştır. Tarafların barış töreninden sonra yeniden çatışmalarını engelleyen faktörler yani caydırıcılığını sağlayan etmenler siyasi partiler üzerinden karşılaştırmalı olarak tartışılmıştır. Bölgede gerçekleştirilen barıştırmalardan “parti”nin gerçekleştirmiş olduklarının bir daha bozulmadığı bütün görüşmecilerce teyit edildiği için bunun arkasında yatan caydırıcılık faktörleri, "örtülü saygı" tanımı ile aktarılmıştır. Barış sağlandıktan sonra çatışmanın yeniden ortaya çıkmayacağının garantisi olmamakla birlikte; görüşmecilerin aktardıkları çatışmayı çözen çatı kurumun bunda etkisinin fazla olduğunu göstermektedir. HDP/BDP HİK temsilcileri ve komisyonda yer alan rusipîler 
Diyarbakır'da partinin çözdüğü hiçbir davadan sonra yeniden çatışmanın ortaya çıkmadığını söylemektedirler. Bunu teyit etmek amacıyla görüşülen diğer siyasi parti temsilcileri, STK yöneticileri ve yereldeki bağımsız rusipîlere bu durumu sorulduğunda o görüşmecilerin hepsi de Kürt kanadının yaptığı barışların bozulduğuna tanıklık etmediklerini aktardılar. Partili kimi HİK temsilcileri kendi siyasi partilerinin barıştırdıkları tarafların yeniden çatışmamasının nedeni olarak toplumun devlete güveni olmadığı için kendilerini ait hissettikleri siyasi parti çatısı altında barış sağlanınca duydukları saygı olarak ifade etmektedirler. Bazı HİK temsilcileri de bunun toplumun bireyler üzerindeki baskısı ile açıklamaktadırlar. Fakat bunu korku faktörü ile açıklayan hiçbir parti temsilcisi olmamıştır. Kendi çözdükleri çatışmalardan sonra barışın bozulup bozulmadığı sorulduğunda AKP, Hüda-Par, CHP ve MHP temsilcileri bazı vakalarda barışın bozulmadığını ama kimi vakalarda çatışmanın yeniden körüklendiğini aktarmışlardır. Bu görüşmecilere göre barış "pamuk ipliğine” bağlı olduğundan her an "kötü niyetli" birilerinin kışkırtması ile yeniden çatışma durumuna dönülebildiğinin ve bunun "barışın doğasında" olduğunu aktarmaktadırlar. Köyde görüşülen bir rusipî barışın kalıcı olmasının nedenini "halk parti için ne duyduğu saygıyı ne de korkuyu devlete karşı duymuyor. Bu yüzden barış için partiye gidiliyor ve parti yapınca barış bozulmuyor” diyerek ifade etmiştir. Toplumun partiye karşı duyduğu örtülü saygının tarafların barıştığı çatışmaların yeniden başlamasını de facto olarak engellediği görülmektedir. Yani Kürt partilerinin caydırıcılık etkisi ne sadece kendilerinin ifade ettikleri gibi tek başına saygı faktörüne bağlı olduğu ne de ana akım medyanın ifade ettiği gibi tek başına korku faktörüne bağlı olmadığı görülmektedir.

Son olarak rusipîlik hukuku ile çözülen vakaların resmi hukuk süreçlerinin nasıl işlediği ve buna çözüm olarak nasıl yöntemlerin geliştirildiği incelenmiştir. Böylece çalışmanın çıkış noktası olan enformel hukukun resmi hukuk sistemine "alternatif" mi yoksa "tamamlayıcı" mı olduğu sorusunun cevabı sahadan elde edilen veriler ve görüşülen hukukçuların beyanları doğrultusunda incelenebilmiştir. Tarafların barıştırılması sürecinde sağladıkları destekle çatı görevi gören siyasi partilerin resmi mahkemelere intikal eden vakalar için de bir çözüm geliştirmişlerdir. Çatışmanın taraflarının avukatları sürece dâhil edilerek resmi hukuki sürecin enformel hukukla sağlanan barışı olumsuz etkilememesi sağlanmaya çalışılmaktadır. Barışan tarafların avukatları bir araya gelerek tarafların en az şekilde etkilenecekleri şekilde ifadelerini vermeleri ve gerekirse dilekçe vermeleri için onları resmi hukuki açıdan yönlendirmektedirler. Resmi hukuk ile kurulan ilişkide taraflar ifadelerini değiştirip, davacı olmasalar bile kamu davasının devam ettiğini bilmektedirler. Avukatlar aracılığıyla yürütülen bu süreçte amaç kamu davasını engellemek olmayıp tarafların en az ceza alarak sağlanan barışı gölgelememesidir. . Görüşülen hukukçular kanaat önderlerinin aynı anda avukatlık, savcılık ve hâkimlik yaptığı bu çatışma çözüm sisteminin Türk hukuk sistemine alternatif ya da paralel bir hukuk sistemi olmadığını ve bundan ziyade "tamamlayıcı" bir hukuk sistemi olduğunu vurgulamışlardır. Hukukçular kanaat önderlerinin arabuluculuk yaptığı rusipîlîk sisteminin alternatif bir hukuk sistemi olmayıp çatışmalı taraflar arasında uzlaşma sağlayan uzlaşma komisyonları olarak gördüklerini belirtmektedirler. Toplumsal barışa katkı sağlayan bu uzlaşma komisyonlarının geleneksel bir hukuk sistemi olduğu için devlete bir tehdit olarak 
görülemeyeceğini ifade etmektedirler. Devletin enformel hukuk sistemini tehdit olarak algılamasının nedeninin devletle örgüt arasındaki "hâkimiyet mücadeledi" olduğu ve bu yüzden de enformel arabuluculuk sistemi Kürt siyasi partilerinin çatısı altında yapıldığında "alternatif" ve "paralel" yapılanmaları olarak görüldüğü için suç unsuru teşkil ettiği belirtilmektedir. Hükümet partisi olan AKP dâhil diğer siyasi partiler de Kürt siyasi partilerini örnek alarak aynı sistemi kurmaya çalıştıkları ve benzer şekilde arabuluculuk yaptıkları halde onların çalışmalarının suç unsuru olarak görülmemesinin temelinde de bu yatmaktadır.

\section{Sonuç}

Devlet-dışı aktör olan enformel arabulucuların toplumsal mikro çatışmaların çözümünde rol almaları hem Çatışma Çözümü'nde Arabuluculuk literatüründeki tartışmalar ekseninde incelenmiş hem de Diyarbakır'daki saha çalışmasından elde edilen veriler ile birlikte değerlendirilerek analiz edilmiştir. Araştırma Diyarbakır il sınırları içinde yer alan ilçe ve köyleri kapsayacak şekilde yapılmasına rağmen çalışmanın çıktılarının bütün şehir için geçerli olduğu belirtilemez. Saha coğrafyasında hangi çatışma türünde resmi mahkemelere ne kadar başvuru olduğu ve ne kadar enformel arabuluculara başvuru olduğuna dair nicel veriler elde edilemediği için sadece enformel arabuluculara yapılan başvurular üzerinden rusipîlik olgusu analiz edilmeye çalışılmıştır. Hem bireysel olarak enformel arabuluculuk yapan hem de kendi çatıları altında bunu organize eden kurumlar ile görüşmeler yapılmış olmasına rağmen bütün kurum ve kuruluşları kapsadığı söylenemez. Araştırmacı uyguladığı etnometodoloji yöntemi ile ağırlıklı olarak etkili olduğu aktarılan aktörler ile görüşmeler yaparak onların anlattıkları doğrultusunda rusipîlik toplumsal olgusunu bütün boyutları ile göstermeyi amaçlamıştır. Bunu yaparken de görüşmecilerin gündelik yaşamda kullandıkları dil aracılığıyla toplumun kültürel kodları yerinde incelenmeye çalışılmıştır. Araştırmanın sonuçları sosyolojik, ekonomik, siyasal ve hukuki başlıklar altında sınıflandırılarak aktarılacaktır:

Araştırmanın sosyolojik sonuçları incelendiğinde geleneksel bir hukuk yöntemi olan ve dünyanın pek çok bölgesinde hala toplumsal çatışmaların çözümünde etkili bir yöntem olarak kullanılan enformel arabuluculuk yönteminin Diyarbakır'da de facto olarak uygulandığ görülmektedir. Toplum tarafından güvenilir, dürüst ve adil olduğuna inanılan; toplumda dini, mesleki ya da aşiretsel/ailevi genel bir statüye sahip olan ve çatışma çözümü için gerekli olan üslup, dil ve geleneklere hakim olan enformel arabulucular eskiden olduğu gibi günümüzde de etkili aktörler olarak bulunmaktadır. Geleneksel olarak enformel hukuka başvurmak için kullanılan "em herin şeriatê" (şeriata gidelim) (Ulutaş, 2015) söyleminin yerini zamanla "em herin cem rusipîya" (rusipîlere gidelim) bıraktığı ve siyasi parti çatısı altında bunun yürütüldüğü son on beş-yirmi yılda ise bunun "em herin partîyê" (partiye gidelim) şeklinde değiştiği görülmektedir. Arabulucuların çatışmanın taraflarından birinin, çevreden birinin ya da kendi inisiyatifleri ile başladıkları arabuluculuk girişimlerinde vakanın anlaşılabilmesi için tarafları ve şahitleri dinleyerek ve araştırma yaparak bir soruşturma yürüttükleri ve bunun sonucunda bir karar verdikleri görülmektedir. Verilen karar her zaman "tarafların barışması" olmakta ve bunun için genelde fail tarafa belli bedelleri yüklenmektedir. Zararın tazmini ve barışın bedeli olarak "her çucikekî gora wî şiv lêxin" (her kuşa bedenine göre sopa vurun) 
Kürtçe atasözünde olduğu gibi herkese kaldırabileceği kadar yük yüklenmeye çalışılmakta ve tarafların ekonomik durumları göz önünde bulundurulurken kolektif suç ve ceza algısından dolayı aileleri de dâhil edilmektedir.

Toplumda suç ve cezanın kolektif olarak algılanması sosyolojik bir olgu olarak var olmakta ve kan davası ve aşiret gibi olguların günümüzde de bunun devam etmesine yardımcı olmaktadırlar. Kolektif sorumluluk ilkesinin etkili olduğu toplumda resmi mahkemelerin ceza vererek tarafların barışmasını sağlayamadığı öldürme gibi vakalarda rusipîlerin tarafların barışmasını sağladıkları görülmektedir. Tarafların bireyler olmasına rağmen bütün aile fertlerinin ve hatta akrabaların suç ve cezada ortak olarak görüldügü ve üstlendikleri öldürme, yaralama, kız kaçırma, aile içi şiddet, arazi, alacak-verecek ve karma çatışma türlerinin hepsinde rusipîlerin tarafları barıştırmada rol aldıkları ve toplumda bu tür çatışmaların çözümünde geleneksel aktörlerin rollerinin önemsendiği görülmektedir. Özellikle öldürme, yaralama ve kan davası vakalarında aradan on yıllar geçse ve fail resmi mahkemelerce hapis cezasına çarptırılıp cezasını çekse bile mağdur taraf için bunun "bir anlam ifade etmediği" ve öç alma saikiyle hareket etmesini engellemediği görülmektedir. Aynı şekilde fail tarafın ailesinin ve akrabalarının da suçu işleyen ve cezayı alan aile üyesine rağmen taraflar arasında barış sağlanmadan kendilerini güvende hissetmedikleri ve bu yüzden de barış sağlanması durumunda failin vermesi gereken bedeli üstlenmeye gönüllü oldukları görülmektedir.

İslami kültürün etkili olduğu toplumda Mele, Seyda, Şeyh ve Hacı gibi dini bir unvana sahip olan rusipîlerin toplum nezdinde etkisinin fazla olduğu ve bu yüzden sol/seküler bir ideolojiye sahip olan siyasi partilerin de kendi çatıları altında gerçekleştirdikleri barıştırma süreçlerinde bu aktörlerle iş birliği yaptıkları görülmektedir. Enformel arabuluculuk sürecinin sonucunda topluma açık gerçekleştirilen barış törenleri ile çatışmanın taraflarının özellikle mağdur tarafin kaybettiği onur/şerefini yeniden kazanması amaç edinilmekte ve toplumun önünde yapılan barışın toplumsal baskı faktörü dolayısıyla caydırıcılık etkisinin arttığı görülmektedir. Caydırıcılığın artırılması için barış törenlerinde dini unvana sahip arabulucular İslami kaynaklara referanslar yaparak barışmanın ve affetmenin önemine dair vaazlar vermekte ve İslami kültürde bulunan Kuran altından geçme ritüeli kullanılmaktadır. Arabuluculukta tarafların sulha ikna edilmesinde İslami din ve kültürü etkili bir referans olarak kullanılmaktadır Geleneksel olarak öğrenilmiş olan barış töreni ritüelleri siyasi partilerin çatısı altında da aynı şekilde uygulandığı görülmektedir. Toplumsal cinsiyet rollerinin geleneksel etkisinin devam ettiği coğrafyada "kadının başındaki beyaz tülbendi atması ile tarafların çatışmaya son verdiği” şeklindeki geleneksel söylemin günümüzde etkili olmadığı fark edilmektedir. Erkeklerin yürüttüğü arabuluculuk süreçlerinde hem çatışmanın tarafları olan kadınlar sürecin dişında tutulmakta hem de kadınların arabuluculuk yapmaları engellenmektedir. Bu durumun istisnası olarak Kürt siyasi partileri bünyesinde Barış Anneleri ve "partili kadınlar" sürece dâhil ediliyormuş gibi gösterilmesine rağmen Barış Anneleri'nin sadece barış törenlerine davet edilerek kendi deyimleri ile "vitrin" görevi gördükleri ve sürece daha fazla müdahil olmalarına izin verilmediği gözlemlenmektedir. Siyasi parti bünyesinde bulunan her HİK'de kadın görevlilerin bulunması zorunlu olmasına rağmen "partili kadınlar" sadece kız kaçırma ve aile içi şiddet vakaları gibi kadınların birebir taraf oldukları vakalarda kadınlarla iletişimin daha rahat sağlanabilmesi için bir araç olarak kullanıldıkları 
görülmektedir. Kadınların da çatışma çözümü sürecinde kendilerinin daha aktif olarak rol almalarına izin verilmediği/alan açılmadığının farkında oldukları ve özellikle öldürme, arazi, alacak-verecek çatışmaları gibi erkeklerin hâkim olarak görüldüğü vakalarda edilgen pozisyonda tutuldukları için bunu eleştirmektedirler. Her ne kadar geleneksel olarak daha öncesinde kadınların enformel arabuluculuk sürecinde aktör olmadıkları ve Kürt siyasi partilerindeki feminist kadın hareketi ile bunun kırılmaya başlandığı ve kadınların da sürece dahil edilmeye başlandığı bilinse bile gelinen noktanın kadınlar açısından yetersiz olduğu görülmektedir. Erkekler söylemlerinde kadınların süreçte daha aktif olarak yer almalarını desteklediklerini belirtmelerine rağmen uygulamaya gelince ağırlıklı olarak kadınlara "alan açmadıkları" ve kendi ailelerinden kadınların aktif olarak yer almalarına izin vermedikleri görülmektedir. Sosyolojik olarak toplumda geleneksel bir hukuk yöntemi olarak görülen rusipîlik sisteminin köyden kente göç etme ve hatta büyükşehir olmasına rağmen ilde hala etkili bir yöntem olduğu görülmektedir.

Araştırmanın ekonomik sonuçları incelendiğinde resmi mahkemelere başvurulduğunda tarafların uzun yıllar süren davalarda karşılaştıkları zorunlu avukat, mahkeme ve ulaşım giderleri gibi harcamaların onların rusipîlere başvurmalarını etkileyen bir faktör olduğu görülmektedir. Mahkeme giderleri dışında özellikle arazi ve alacak-verecek çatışmaları gibi birebir ekonomik sonuçların doğacağı çatışmalarda yıllar süren davalar sonucunda yine de haklarını alamayacaklarını düşünen tarafların bunun yerine davaları daha kısa sürede çözen rusipîleri tercih etmelerinde etkili olmaktadır. Hiçbir ekonomik beklentileri olmadan, tamamen karşılıksız olarak ve kendi söylemleri ile "Allah rızası için” arabuluculuk yapan rusipîlerin uzun zaman alan ve taraflar arasında mekik dokumalarını gerektiren çözüm sürecinde ulaşım giderleri dâhil hiçbir beklentileri olmadığı görülmektedir. Ayrıca fail tarafın bedel ödemesine karar verilen vakalarda eğer fail tarafın maddi gücü bunu karşılayamayacak durumda ise arabulucuların "hayırseverler"den yardım topladıkları ve eksik kaldığında kendi ceplerinden eksiği karşıladıkları bilinmektedir. $\mathrm{Bu}$ durum hem fail taraftan alacağını alamayacak olan mağdur taraf açısından en azından alacağının bir kısmını kurtarmasını sağladığı için hem de fail tarafın ödemek zorunda kaldığı bedelin paylaşılarak yükünün azalmasına yardım ettiği için her iki taraf açısından da bu yöntemin tercih edilmesinde etkili olmaktadır. Ayrıca saha coğrafyasında "hayırsever" olarak tanımlanan ve ekonomik durumu iyi olan kişiler açısından bu tür çatışmaların çözümüne ekonomik olarak katkı sağlamak; kimin destek olduğu herkes tarafindan öğrenildiği/duyulduğu için bu durum toplumdaki statülerinin güçlenmesini ve onlara duyulan saygının artmasını sağladığından dolayı yardımcı olmayı hem bir "hâyır" hem de toplumsal bir kazanç olarak gördükleri anlaşılmaktadır.

Öldürme ve yaralama gibi vakalarda resmi yasalarda mağdura verilmesi gereken herhangi bir tazminat türü bulunmadığı için faillerin ceza alması mağdur aile açısından kaybettikleri onur/şereflerini geri kazanmalarını sağlamadığı gibi maddi kayıplarını da karşılamamaktadır. Özellikle öldürme vakalarında kurbanın kaybı ile ailede oluşacak maddi kayıp göz önünde bulundurularak rusipîlerin ailenin ya barınabilmesi için "ev alacak kadar" ya da geçimini 
sağlayabilmesi için “iş kurabileceği kadar” bir kan parasını meblağına karar verdikleri görülmektedir. Bütün vakalarda bu temel kıstas olmamasına rağmen ekonomik gücü iyi olan mağdur ailelerin barış törenlerinde onlara verilen kan parasını "cemaatin hatırı için bağışlamalarında" ekonomik faktörün etkili olduğu görülmektedir. Fail taraf açısından da barış için ödemekle yükümlü kılındığı kan parasını tek başına ödemesi ekonomik olarak onları olumsuz etkileyeceği için bunun diğer akrabalar ve hayırseverler tarafindan da yüklenilmesi ve onların yüklerinin azalması önemli bir ekonomik faktör olarak görünmektedir. Kız kaçırma vakalarında resmiyette 18 yaşını geçmiş olan kadının ailesinin müdahale edebileceği bir durum olmadığından dolayı rusipîler aracılığıyla yapılan barışmalarda başlık parası alınabildiği görülmektedir. Başlık parası saha coğrafyasında hala yaygın bir uygulama olduğu için ve kaçma/kaçırılma vakalarında verilecek başlık parasının miktarı normal istemeye göre daha fazla olduğu için kadının ailesi açısından ekonomik ve toplumsal bir kazanım olarak görülmektedir. Geleneksel olarak "başlık parası fazla olan geline eşinin ailesinin daha fazla değer vereceği” inanışı hala dile getirilmekte ve başlık parası alındığı takdirde bunun kızlarının eşinin ailesindeki konumunu ve gücünün de artıracağına inanılmaktadır. Ayrıca çok çocuklu olan ailelerde kızlarının kaçması sonucu alınan başlık parası başka bir erkek çocuklarını evlendirmek için harcayacakları masrafların bir kısmını ödemek için kullanıldığından dolayı başlık parasının doğal ve gerekli görüldüğü gözlemlenmektedir. Her ne kadar rusipilere başvurulmasını etkileyen ekonomik faktörlerin az olduğu düşünülmüş olsa da saha çalışmasında ekonomik faktörlerin de etkili olduğu görülmüştür.

Çalışmanın siyasal sonuçları incelendiğinde ilk olarak geleneksel bir yöntem olan rusipiliğin günümüzde Kürt siyasi partileri çatısı altında gerçekleşen yeniden inşa süreci dikkat çekmektedir. Kürt siyasi partisinin geleneksel bir yöntem olan rusipîliği dönüştürerek bir sistem kurduğu ve onu kurumsallaştırmaya çalıştı̆̆ı görülmektedir. Ehrlich (1913)'in "yaşayan hukuk" (living law) kavramı ile açıkladığı gibi toplum içinde yaşayan enformel hukuku, bir çatı altında kurumsallaştırdıkları görülmektedir. Yani aslında parti sıfırdan bir enformel hukuk sistemi kurmamış ve toplumda yaşayan hukuku aktörleri ile birlikte kendi çatısı altında yeniden inşa etmiştir. De facto olarak işlev gören bu sistemin toplum nezdinde de kabul gördüğ̈, enformel arabuluculara başvuran kesim içinde bireysel arabulucular da dahil yüzde seksen/doksan oranında partiye başvurmalarından anlaşılmaktadır. Diğer siyasi partiler bu sistemin geleneksel bir yöntem olduğunu belirtip onu örnek alarak bir sistem kurmaya çalışsalar da onlar kadar kapsamlı ve talep gören bir yapı oluşturamadıklarının farkındadırlar. Diğer siyasi partilerin arabuluculuk yapmaya çalışsalar da caydırıcılık etkileri ve toplum nezdindeki başvuruları partinin toplum üzerindeki etki oranı ile kıyaslanamayacak kadar küçük kalmaktadır.

Partinin gelenekseli dönüştürdüğü bu sistemin rağbet görmesinde yapılan barışın kalıcı olmasının etkili olduğu yani enformel olan yöntemle bile caydırıcı olabilmeleri etkili olmaktadır. Partinin caydırıcılığını sağlayan ve onu diğer siyasi partilerden ayıran nokta ise 
“dağdaki”’lerin gücü ve caydırıcılığından yararlanmasıdır. Toplumda partiye yönelik saygı, korku veya çekince şeklinde ifade edilen "örtülü saygı"nın kaynağında "dağdakilerin" köylerde yaptıkları arabuluculuk girişimlerin hafizalarda hala taze olmasının etkili olduğu görülmektedir. Ayrıca “örtülü saygı"nın caydırıcılığı beraberinde "partinin yaptığı barış bozulmaz" algısını oluşturduğu için bu durum toplumda partiye daha fazla başvuru yapılmasını sağlamaktadır. Yani partinin yaptığı barış caydırıcılık etkisi ile bozulmadığı için bu durum aralarında korucuların ve coğrafyaya tayini çıkmış devlet memurlarının da olduğu kişilerin bile çatışmalarını kısa yoldan ve etkili bir şekilde çözmeleri için partiye başvurmalarını sağlamaktadır. Ayrıca coğrafyada yüzde 60-70'lerde oy oranına sahip olan partinin ilin bütün ilçelerinde aktif parti teşkilatları bulunduğu için bu teşkilatların rusipîlere lojistik destek vermelerini kolaylaştırmaktadır. Siyasi partinin teşkilatının Diyarbakır'ın bütün bölgelerinde etkili olan rusipîleri araştırma, onlarla temasa geçme ve davaların çözümü için yardım istemeyebilmeleri için bağlantılar oluşturmalarını sağlamaktadır. Geleneksel olarak eskiden beri toplum içindeki davaları hiçbir karşılık beklemeden çözen rusipîler zaten çözülmesini istedikleri davaların partinin caydırıcılık ve güç şemsiyesi altında yapmakta bir sorun görmemektedirler. Bundan dolayı da rusipîler bir davanın çözülmesi için "kimden teklif gelirse gelsin" yardımcı olduklarını aktarmaktadırlar. Partinin de barıştırma için kim arabulucu olabilecekse ondan yardım talep ettiği görülmektedir. Coğrafyada etkili olan makro çatışma olan Kürt meselesi toplum içindeki mikro-çatışmaların çözüm aktörlerini de etkilemekte ve toplumun bir kesiminin güvenmediği resmi kurumlar yerine aidiyet hissettikleri partiye başvurmalarında etkili olmaktadır. Partinin de bunun bilincinde olarak siyasal gücünü ve nüfuzunu artırmak için rusipîlik sistemini bir araç olarak kullandığ görülmektedir. Toplumsal bilincin artırılması için rusipiliğin bağımsız bir şekilde kurumsallaşmasını istediklerini aktarmalarına rağmen; bağımsızlaşan Farqin Rusipî Derneği örneğinde bu tür bir girişim gerçekleştiğinde kendi güç ve nüfuz araçlarından birini kaybedecekleri için buna olumlu tepki göstermedikleri görülmektedir.

Çalışmanın hukuki sonuçları incelendiğinde hukukçular Türk hukuk sisteminin Türkiye toplumuna uymayan, batıdan ihraç edilmiş ve tepeden inme bir hukuk sistemi olduğu için toplumsal çatışmaların çözümünde etkisiz kaldığını belirtip arabuluculuk sistemini tamamlayıcı bir hukuk sistemi olarak gördüklerini aktarmaktadırlar. Buna rağmen Kürt siyasi partileri tarafından dönüştürülen bu enformel hukuk sisteminin, devlet eliyle tamamlayıcı bir hukuk sistemi olarak kurulmasının aynı etkiyi yaratmayacağını da itiraf etmektedirler. Özellikle coğrafyadaki makro çatışmanın toplumun resmi kurumlara karşı olan güvenlerini etkilediği bilindiği için o çözülmeden resmi arabuluculuk benzeri ve rusipîlerin aktör olarak yer aldıkları bir arabuluculuk sisteminin devlet eliyle kurulmasının partiler üstü bir yapıda olsa bile toplumda var olan enformel hukukun yerine geçemeyeceği düşünülmektedir. Devletdışı aktörlerin toplum içindeki mikro çatışma çözümündeki rolleri incelendiğinde sahadan elde edilen verilerin geleneksel bir yöntemin devamı mı yoksa alternatif bir hukuk inşası mı olduğu temel sorulardan birini oluşturmaktaydı. Hem yapılan görüşmeler hem katılımcı gözlemci olarak bulunulan toplantılar hem de halk içinde yapılan sohbetlerde bunun geleneksel bir yöntem olan enformel hukuk sisteminin parti çatısı altında dönüşümü, yani 
yeniden inşa süreci olduğu görülmektedir. Bu sistem de facto olarak toplum nezdinde kabul gören ve toplumsal barışa katkı sağladığına inanılan bir mekanizma olarak işlemektedir. Parti açısından da bu mekanizmanın toplum üzerindeki gücünü ve nüfuzunu pekiştirmesine katk1 sağladığı da aşikârdır. Diğer siyasi partilerin de Kürt siyasi partilerini örnek alarak, rusipîlîk geleneğinin yeniden inşasını güç ve nüfuzlarını artırmak için bir araç olarak kullandıkları görülmektedir.

Enformel hukuk sistemi olan rusipiliğin Kürt siyasi partisi dışında diğer siyasi partilerin çatısı altında gerçekleştirildiğinde bunun devlete ve resmi mahkemelere bir tehdit, "alternatif” ya da "paralel” olarak görülmediği anlaşılmaktadır. Bütün siyasi partilerin bu sistemi toplum ve seçmenleri üzerindeki güç ve nüfuzlarını artırmak için kullanmalarına rağmen sadece Kürt siyasi partileri tarafından gerçekleştirildiğinde suç unsuru olarak görüldüğü, çatışmanın tarafları ve rusipîler suçlu olarak görülmezken partinin HİK üyelerine KCK iddianameleri bağlamında davalar açıldığı bilinmektedir. Bu durum aslında mikro çatışmaların çözüm yöntemlerinin makro çatışma ile ne kadar ilgili olduğunu ve makro çatışmada devletin ve diğer aktörlerin kurdukları ilişkilerin mikro çatışmadaki aktörler ile kurdukları ilişkileri de etkilediğini göstermektedir. Çalışmanın hukuki sonuçları özetlenecek olursa mikro çatışmaların çözümünde resmi mahkemelerde kamu davaları devam ettiği için ve rusipîlerin hapsetme gibi cezalandırıcı kararlar verme gibi bir yetkileri, istekleri ve yapıları bulunmadığından dolayı enformel arabuluculuk sisteminin resmi hukuka "paralel" ya da "alternatif" bir sistem olmadığı ve devletin hakimiyet alanına tehdit oluşturmadığ görülmüştür. Geleneksel bir yöntem olan rusipiliğin siyasi partilerin çatısı altında yeniden inşa edilmesi büyükşehir olan bir ilde insanların toplumsal çatışma çözümü için başvuracakları "kapıyı" yani adresleri bilmelerini sağlamıştır. Zaten bütün görüşmecilerin de belirttiği üzere genellikle herkes kendi siyasi görüşüne yakın gördüğü siyasi partilere başvurduğu için kimsenin bunun için zorlanmadığı ve kişilerin tercih ettikleri görülmektedir. Ayrıca siyasi partilerin çatısı altında yapılan barıştırma girişimlerinde de temel kural çatışmanın taraflarının buna izin vermesi yani "yetki vermeleri” olduğu için coğrafyadaki hiçbir rusipî ya da siyasi parti çatışmanın tarafları izin vermediği sürece dâhil olmamaktadırlar. Ayrıca siyasi partilerin bireysel arabulucuların dâhil olduğu ikinci eş, uyuşturucu, fuhuş ve faiz gibi çatışmalara dâhil olmadıkları ve bunları kırmızıçizgileri olarak gördükleri için toplumsal ahlaka dikkat ettikleri görülmektedir. Toplumdaki ilişkilerin düzenlenmesi için olmazsa olmaz olan resmi hukuk toplumun bütün ana damarlarına inebilirken "kılcal damarlarına" inemediği anlaşılmaktadır. Suç ve cezanın kolektif olarak görüldügü toplumda çatışmanın tarafları arasında toplumsal barışın sağlanması için geleneksel aktör olan rusipîlerin bireysel ya da bir siyasi parti çatısı altında arabuluculuk yapması “tamamlayıcı" bir hukuk sistemi olarak görülmektedir.

Yeni Araştırma Perspektifleri düşünüldüğünde Diyarbakır'da gerçekleştirilen bu çalışmanın ortaya çıkardığı sonuçlar yeni çalışmalara öncülük edebilir. Dünyada on yılardır var olan ve giderek etkisi artan çatışma çözümü literatüründeki çalışmaların Türkiye'de son on yılda 
araştırılmaya başlandığı görülmektedir. Ne var ki çatışma çözümü çalışmaları başta Kürt meselesi olmak üzere toplumda var olan makro çatışmalar üzerinden araştırılmaktadır. Toplumsal mikro çatışmaların çözümünde arabuluculuk ve çatışma çözümü literatürü kapsamında yapılan çalışma bulunmamaktadır. Bu çalışma bu alanda ilk olduğu için giriş niteliği taşımaktadır. Özellikle Kürt coğrafyasında mikro çatışmaların enformel arabulucular aracılığıyla çözüldüğü bilinmektedir. Diyarbakır örneğinde bunun siyasi partilerin çatısı altında yeniden inşa edildiği ve kurumsallaştığı görülmüştür. Ne var ki coğrafyanın aşiret olgusunun daha güçlü olduğu, daha laik ve dini cemaatlerin daha güçlü olduğu muhafazakâr il ve bölgelerinde hangi aktörler aracılığıyla arabuluculuğun yapıldığına dair çalışmalar mevcut değildir. Bu çalışmanın Kürtlerin yaşadıkları coğrafyada yapılacak gelecek çalışmalara karşılaştırma yapılabilmesi açısından veri sağlayacağı görülmektedir. Ayrıca Türkiye'de sadece Kürtlerin yoğunluklu olarak yaşadıkları coğrafyada değil bütün bölgelerinde enformel arabulucular aracılığıyla yürütülen enformel hukuk sistemlerinin araştırılması ve bunun bir haritasının çıkarılması önemli görülmektedir. Kan davasının sadece Kürtlerin yaşadıkları coğrafyada etkili olduğu ön kabulü Ünsal (1995)'ın Anadolu'da Kan Davası çalışması ile Karadeniz Bölgesi'nde Doğu Anadolu Bölgesi'nden daha fazla gerçekleştiğinin ortaya çıkarılması ile değiştirilmiştir. Dolayısıyla bu çalışmanın adı rusipî, kanaat önderi ya da ne olursa olsun enformel arabulucuların mikro çatışmaların çözümündeki rollerinin bütün Türkiye'de karşılaştırmalı olarak incelenmesi için bir giriş niteliğinde olacağ1 düşünülmektedir. Ayrıca, bu çalışmanın ortaya çıkardığı enformel arabulucular aracılığıyla toplumun mikro çatışmalarını nasıl çözdüklerinin toplumdaki makro çatışmaların çözümü için de yeni yöntemler bulunmasına katkı sağlayacağı ve bu konuda yapılacak araştırmalar için veri sunacağını düşünülmektedir.

\section{KAYNAKÇA}

Abu-Nimer Mohammed (2001). Conflict Resolution, Culture, and Religion: Toward a Training Model of Interreligious Peacebuilding, , Journal of Peace Research, Vol. 38, No. 6 (Nov.,), pp. 685-704.

Abu-Nimer Mohammed (2004). Religion, Dialogue, and Non-Violent Actions in PalestinianIsraeli Conflict, International Journal of Politics, Culture, and Society, Vol. 17, No. 3 (Spring,), pp. 491-511.

Abu-Nimer Mohammed(2006). Framework for Nonviolence and Peacebuilding in Islam, Contemporary Islam, Abdul Aziz Said, Mohammed Abu-Nimer and Meena SharifyFunk, Dynamic, not Static, Routledge: 131-172.

Abu-Nimer Mohammed (2011). Religious Leaders in the Israeli-Palestinian Conflict: From Violent Incitement to Nonviolence Resistance, PEACE \& CHANGE, Vol. 36, No. 4, October. 
Appleby R. Scott. (2000). The Ambivalence of the Sacred: Religion, Violence and Reconciliation (Lanham, MD: Rowman \& Littlefield.

Auerbach Yehudith (2005) Forgiveness and Reconciliation: The Religious Dimension, Terrorism and Political Violence, 17:3, 469-485, DOI: 10.1080/09546550590929174.

Aquino Corazon (2008). Conflict Resolution as a Normative Value in Islamic Law: Handling Disputes with Non-Muslims.

Aydın Murat Burak (2016). “Japonya'da Alternatif Uyuşmazlık Çözümü, Türkiye’de Arabuluculuk ve Yaşayan Hukuk”, Prof. Dr. Adnan Güriz’e Armağan, (der. Sami Üye ve diğ.), Ankara, 155-177

Bakırcı, M. (2014). Doğu Karadenizde Bir Köy İmamı: Balcı Hoca (Hasan Balcığlu). Journal of International Social Research, 7(32), ss: 355-371.

Bercovitch, Jacob and Rubin Jeffrey Z.(ed.) (1992). Mediation in International Relations: Multiple Approaches to Conflict Management, London: Palgrave.

Bercovitch Jacob. (1996). "The Structure and Diversity of Mediation in IR" in Bercovitch, Jacob and Rubin Jeffrey Z.(ed.) Mediation in International Relations: Multiple Approaches to Conflict Management, London: Palgrave.

Bush Robert A. Baruch, Joseph P. Folger (2005). The Promise of Mediation, Jossey-Bass Press, San Francisco.

Chirayath Leila, Caroline Sage and Michael Woolcock (2005). "Customary Law and Policy Reform: Engaging with the Plurality of Justice Systems" July 2005, world Development Report 2006: Equity and Development.

Cloke Kenneth (2001). Mediating Dangerously: The Frontiers of Conflict Resolution, Josseybass Publishers, San Francisco.

Davis, H. E. Ve Dugan, M. A. (1982). “Training the Mediator”, Peace and Change, Volume 8, Issue 2-3, 81-90.

Deutsch Morton (1985). Distributive Justice: A Social Psychological Perpsective, New Haven: Yale University Press.

Douglas Johnston (ed) (2003). Faith-Based Diplomacy: Trumping Realpolitik, Oxford University Press..

Fox Jonathan (2000) The ethnic-religious nexus: The impact of religion on ethnic conflict, Civil Wars, 3:3, 1-22. 
Frydenberg Erica (2005). Morton Deutsch: A Life and Legacy of Mediation and Conflict Resolution, Australian Academic Press, Brisbane.

Irani George E (1999). "Islamic Mediation Techniques for Middle East Conflicts," Middle East Review of International Affairs, 3: 2, 1-17

Hare Paul (1992). "Informal Mediation by Private Individuals" in Bercovitch, Jacob and Rubin Jeffrey Z.(ed.) Mediation in International Relations: Multiple Approaches to Conflict Management, London: Palgrave.

Habermas, J (1989). The Structural Transformation of the Public Sphere, Cambridge:Polity Press.

Johnstone, G (2002). Restorative Justice: Ideas, Values, Debates, Cullompton: Willan Publishing.

Kaya, Mahmut (2013). Modernleşme Sürecinde Aşiretlerin Dönüşümü: Sanlıurfa Aile ve Aşiret Dernekleri, Selçuk Üniversitesi, Yayınlanmamış Doktora Tezi.

Kekeç Elif Kısmet (2010). Arabuluculuk Yoluyla Uyuşmazlık Çözümünde Temel Aşamalar ve Taktikler, Dokuz Eylül Üniversitesi, Yayınlanmamış Doktora Tezi.

Kelman Herbert C (1992). "Informal Mediation by the Scholar/Practitioner" in Bercovitch, Jacob and Rubin Jeffrey Z.(ed.) Mediation in International Relations: Multiple Approaches to Conflict Management, London: Palgrave.

Kriesberg, Louis (1973). The Sociology of Social Conflicts, Prentice-Hall, USA.

Kümbetoğlu, Belkıs (2012). Sosyolojide ve Antropolojide Niteliksel Yöntem ve Araştırma, (3. Bask1), İstanbul: Bağlam Yayınları.

Lederach, Paul. (2005). The moral imagination: The Art and Soul of Peacebuilding. Oxford: Oxford University Press.

Maoz Ifat (2004). Peace Building in Violent Conflict: Israeli-Palestinian Post-Oslo People-toPeople Activities, International Journal of Politics, Culture, and Society, Vol. 17, No. 3 (Spring), pp. 563-574.

Nadia Mahmoud Mostafa (2006). The Missing Logic in Discourses of Violence and Peace in Islam, Abdul Aziz Said, Mohammed Abu-Nimer and Meena Sharify-Funk, Dynamic, not Static, Routledge,173- 189.

Ökten, Şevket (2010). "Kan Davası: Kanın Öcü ya da Şeref Uğruna Verilen Kolektif Savaş”, Ankara Üniversitesi Antropoloji Dergisi, 165-187. 
Özbek, Mustafa (2005). “Avrupa Konseyi Bakanlar Komitesi’nin “Ceza Uyuşmazlıklarında Arabuluculuk” Konulu Tavsiye Kararı”, Dokuz Eylül Üniversitesi Hukuk Fakültesi Dergisi Cilt: 7, Say1: 1, s. 127-166.

Özbek Mustafa (2007). Avrupa Birliği'nde Alternatif Uyuşmazlık Çözümü, TBB Dergisi, Sayı 68, 265-320.

Öztürk Hatice (2016). Arabuluculuk Eğitimlerinde Eğitmen Tutum ve Görüşlerine Yönelik Bir Araştırma: Türkiye Barolar Birliği Modeli, Yayınlanmamış Yüksek Lisans Tezi, Başkent Üniversitesi.

Pavlich, G, (1996). Justice Fragmented: Mediating Community Disputes Under Postmodern Conditions, London: Routledge.

Parkinson, J and Roche, D, (2004). 'Restorative justice: deliberative democracy in action?',Australian Journal of Political Science, 39:3, pp 505-18. (aktaran) Andrew Woolford and R.S. Ratner, Conflict Resolution in Mediation, Restorative Justice and Reparations, Routledge-Cavendish.

Perreau-Saussine Amanda, Murphy J. Bernard (2007). The Nature of Customary Law, Cambridge University Press, UK..

Raymond G. Helmick and Rodney L. Peterson (eds) (2001). Forgiveness and Reconciliation: Religion, Public Policy, and Conflict Transformation (Philadelphia: Templeton Foundation Press, 129-149.

Said, A. and Funk, N. (2002). The Role of Faith in Cross Cultural Conflict Resolution. Peace and Conflict Studies, Vol 9(1) 37-50.

Saxon Erin Dyer (2018). Peacemaking and Transformative Mediation: Sulha Practices in Palestine and the Middle East, The Palgrave Macmillian, Switzerland.

Shore Megan (2009). Religion and Conflict Resolution: Christianity and South Africa's Truth and Reconciliation Commission, Ashgate Publishing.

Şimşek, Nevin ve Fidan, Mehmet (2005). Kurum Kültürü ve Liderlik. Konya: Tablet Kitabevi.

Tunç, Nazım (2010). Ceza Muhakemesi Hukukunda Uzlaştırma, Bilecik Üniversitesi Sosyal Bilimler Enstitüsü Yüksek Lisans Tezi.

Touval, S. ve Zartman, W. (1985), "International Mediation: Conflict Resolution and Power Politics", Journal of Social Issues, Volume 41, Issue 2, 27-45.

Ulutaş Ejder (2015). Toplumsal Bir Tip: Kanaat Önderi, Yayınlanmamış Doktora Tezi, Selçuk Üniversitesi. 
Uzma Rehman (2011). Conflict Resolution and Peacemaking in Islam: Toward Reconciliation and Complementaritybetween Western and Muslim Approaches, , Islamic Studies, Vol. 50, No. 1 (Spring), pp. 55-69.

Ünsal Altun (1995). Anadolu'da Kan Davası: Yaşamak için Öldürmek, YKY.

van Bruinessen, Martin (1991). "Kurds, states and tribes”, in Faleh A. Jabar and Hosham Dawod (eds.), Tribes and power: nationalism and ethnicity in the Middle East. London: Saqi, , pp. 165-183.

van Bruinessen, Martin (2002). Ağa, Şeyh, Devlet. (6. Baskı). (çev: Banu Yalkut). İstanbul: İletişim Yayınları.

van Bruinessen, Martin (2003). Kürtler, Devletler ve Aşiretler. (Der: Faleh A. Jabar\&Hosham Dawod). Aşiretler ve İktidar Ortadoğu' da Etnisite ve Milliyetçilik. İstanbul: Bilgi Üniversitesi Yayınları, ss: 159-176.

Wardak Ali (2004). Building a post-war justice system in Afghanistan, Crime, Law \& Social Change 41: 319-341, 319-341.

Woolford Andrew and R.S. Ratner (2008). Conflict Resolution in Mediation, Restorative Justice and Reparations, Routledge-Cavendish.

Yassine- Hamdani, Nahla and Pearson, Frederic S. (2014) “Arab Approaches to Conflict Resolution: Mediation, Negotiation and Settlement of Political Disputes, Routledge, New York.

Yıldırım, Ali ve Şimşek, Hasan (2013). Sosyal Bilimlerde Nitel Araştırma Yöntemleri. (9. Baskı). Ankara: Seçkin Yayıncılık.

Y1lmaz Muzaffer Ercan. (2012). “Türkiye'de Arabuluculuk Uygulamaları”, İnsan ve Toplum Bilimleri Araştırmaları Dergisi, Cilt.1, Sayı: 3 - Volume.1, Issue: 3, 7-16.

Zartman I. William ,Saadia Touval (1985). International Mediation: Conflict Resolution and Power Politics, Journal of Social Issues, Volume41, Issue2, Summer, 27-45.

Zehr, Howard (1990). Changing Lenses: A New Focus for Crime and Justice, Scottdale, PA: Herald.

Afganistan Büyükelçiliğii: http://afghanembassy.org.tr/tr/contact/info/afghanistannn (E.T. 12/05/2018)

Wi'am: http://www.alaslah.org/sulha/ (E.T. 12/05/2018) 
"PKK Mahkeme Kurdu” 20 Eylül 2014, http://www.haberinadresi.com/pkk-mahkemekurdu-h56342.html (E.T. 10/11/2018) 